This is a first page of PREPRINT version (pre-refereeing process) of the original paper: Esteban-Arispe, I., Velasco-Roldán, F., Boyce, A.J, Morales-Ruano, S., Yusta, I., Carrillo-Rosúa, J. (2016). Unconventional non-magmatic sulfur source for the Mazarrón Zn-Pb-Cu-Ag-Fe epithermal deposit (SE Spain). Ore Geology Reviews, 72, 1102-1115. doi: http://dx.doi.org/10.1016/j.oregeorev.2015.10.005.

The original paper is in: http://www.sciencedirect.com/science/article/pii/S0169136815301013

\title{
Unconventional non-magmatic sulfur source for the Mazarrón Zn-Pb-Cu-Ag-Fe epithermal deposit (SE Spain)
}

\author{
Esteban-Arispe, Iñaki ${ }^{a^{*}}$, Velasco, Francisco ${ }^{b}$, Boyce, Adrian J. ${ }^{c}$, Morales-Ruano, \\ Salvador ${ }^{a, d}$, Yusta, Iñaki ${ }^{b}$, Carrillo-Rosúa, Javier ${ }^{d, e}$ \\ ${ }^{a}$ Departamento de Mineralogía y Petrología. Facultad de Ciencias, Campus Fuentenueva, Universidad de \\ Granada, 18002 Granada (Granada, Spain) \\ ${ }^{b}$ Departamento de Mineralogía y Petrología. Facultad de Ciencia y Tecnología. Universidad del País Vasco, \\ 48940 Leioa (Vizcaya, Spain) \\ ' Scottish Universities Environmental Research Centre (SUERC). Rankine Avenue, Scottish Enterprise \\ Technology Park, East Kilbride G75 OQF (Scotland, UK) \\ ${ }^{d}$ Instituto Andaluz de Ciencias de la Tierra (UGR-CSIC). Avda. de las Palmeras № 4, 18100 Armilla (Granada, \\ Spain) \\ ${ }^{e}$ Departamento de Didáctica de las Ciencias Experimentales, Facultad de Ciencias de la Educación, Campus \\ Universitario de Cartuja, Universidad de Granada, 18071 Granada (Granada, Spain)
}

\begin{abstract}
Geological evidence and mineralogical, fluid inclusion temperature and geochemistry data suggest that the Mazarrón $\mathrm{Zn}-\mathrm{Pb}-\mathrm{Cu}-\mathrm{Ag}-\mathrm{Fe}$ deposit is a volcanic-hosted epithermal deposit, in that it is hosted by dacites with advanced argillic alteration, argillic alteration, propylitic hydrothermal alteration and silicification halos. K-Ar dating of illite from the argillic hydrothermal alteration gives an age of $9.7 \pm 1.2 \mathrm{Ma}$, which suggests that mineralization took place very close to the volcanism. The fluid inclusion study in the ore veins shows epithermal temperatures (between 190 and $260^{\circ} \mathrm{C}$ ), but moderate salinities, between 12 and $18 \mathrm{wt}$. \% $\mathrm{NaCl}$ eq), compatible with mixing between surface waters and polygenic deep hydrothermal fluids. Two mineralization types are identified: iron sulfide mineral association and polymetallic mineral association (sphalerite-galena-chalcopyrite-fahlore bearing). According to isotopic data, the first mineralization was mainly formed by interaction between basinal fluids that leached Triassic sulfates (+ surface waters), and C-bearing reduced deep waters. This interaction developed a Thermochemical Sulfate Reduction (TSR) supporting extreme and geologically unusual fractionation, with a range up to $+30 \%$ o $\delta 34 \mathrm{~S}$, and reaching $+53 \%$ o $\delta 34 \mathrm{~S}$. The second mineralization event is compatible with the irruption of a magmatic fluid discharge. Although this study suggests that Mazarron could be classified as an intermediate sulfidation deposit, the genetic model includes processes such as TSR that are not typical features of volcanic-hosted epithermal deposits.
\end{abstract}




\section{KEYWORDS}

Unconventional epithermal volcanic-hosted; SE Spain; Stable and radiogenic isotopes; Thermochemical sulfate reduction

*Corresponding author.

Iñaki Esteban Arispe $(\varangle)$, Departamento de Mineralogía y Petrología, Facultad de Ciencias. Universidad de Granada, Fuentenueva s/n, 18071-Granada

E-mail: iesteban@ugr.es

\section{Introduction}

The Cabo de Gata-Cartagena volcanic belt in SE Spain hosts several gold-silver and base metal epithermal volcanic-hosted deposits with both high and low sulfidation (e.g. San José, Rodalquilar, Carboneras, Mazarrón; Arribas and Tosdal, 1994; Morales et al., 2000; CarrilloRosua et al., 2003; Crespo et al., 2013). The Rodalquilar deposit is considered one of the best examples in the world of a high-sulfidation deposit (Arribas et al., 1995; Hedenquist et al., 2000), and was once the most gold-rich epithermal deposit in Spain. Little research has been done however on the Cu-rich Mazarrón deposit, which is considered one of the biggest basemetal-rich deposits in the Cabo de Gata-Cartagena belt.

Many of the characteristics of the Mazarrón deposit, including host rock type, vein style, mineral associations and hydrothermal alteration halos (Morales Ruano and Fenoll Hach-Alí, 1990; Arana et al., 1993; Oyarzun et al., 2011, this paper) support its epithermal nature consistent with a magmatic-hydrothermal system. Nevertheless, there is a lack of consensus as to its classification (low sulfidation by Hedenquist et al., 2000; high sulfidation by Oyarzun et al., 2011), due to a shortage of data. According to genetic models, a volcanic-hosted epithermal deposit such as the Mazarrón deposit would be expected to have a magmatic sulfur source. However, the isotopic data presented in this paper demonstrate that most of the sulfur in the deposit is incompatible with a source of this kind. The sulfide and sulfate minerals from this deposit show an unusually wide range of $\delta^{34} S$ values, with sulfur that is too enriched to be the product of a single magmatic sulfur source. This study therefore has two aims. Firstly, to describe and briefly analyze the principal geological and mineralogical characteristics of the epithermal Zn-Pb-Cu-Ag Mazarrón deposit, offering new data. Secondly, to examine the origin of the sulfur and the fluids in order to characterize alternative sources not normally associated with an epithermal volcanic-hosted deposit. In relation to this second aim, a hypothesis emerged as to the possible intervention of basinal sedimentary brine. The Mazarrón deposit could be the product of a complex hydrothermal system that began in the Miocene ( $\sim 10 \mathrm{Ma}$ ). Ore-forming processes, magmatism, $\mathrm{CO}_{2}$ degasification and geothermal activity (Crespo et al., 2013) seem to be closely related in a context that is favored by significant tectonic activity (Pérez del Villar et al., 1998).

\section{Geological setting}

The $\mathrm{Zn}-\mathrm{Pb}-\mathrm{Cu}-\mathrm{Ag}$ Mazarrón deposit is located in the northern part of the Cabo de GataCartagena volcanic belt (Fig. 1) at the eastern end of the Betic Cordillera (southern Spain). This volcanic field, which also continues under the Alboran Sea and northern Morocco, developed during the Miocene (and probably also during the Pliocene). There is some 
debate as to its origin (Turner et al., 1999; Peccerillo and Martinotti, 2006; Conticelli et al., 2009), but authors generally agree that it is linked to extensional processes that took place after the important compressive regime that produced the Betic Cordillera, when Africa and Europe converged. Decompression caused the fusion of mantle materials, previously metasomatized by subduction processes (Blanco and Spakman, 1993; Benito et al., 1999). The rising melts underwent various processes (interaction and assimilation of cortical rocks, differentiation and fractionation according to López-Ruiz and Rodríguez-Badiola, 1980), which permitted the formation of different types of magma (roughly, from southwest to northeast): calc-alkaline, high-K calc-alkaline and shoshonitic, ultrapotassic rocks and rare alkaline basaltic rocks. Toleithic magmatism is also common under the Alboran Sea (Duggen et al., 2008).

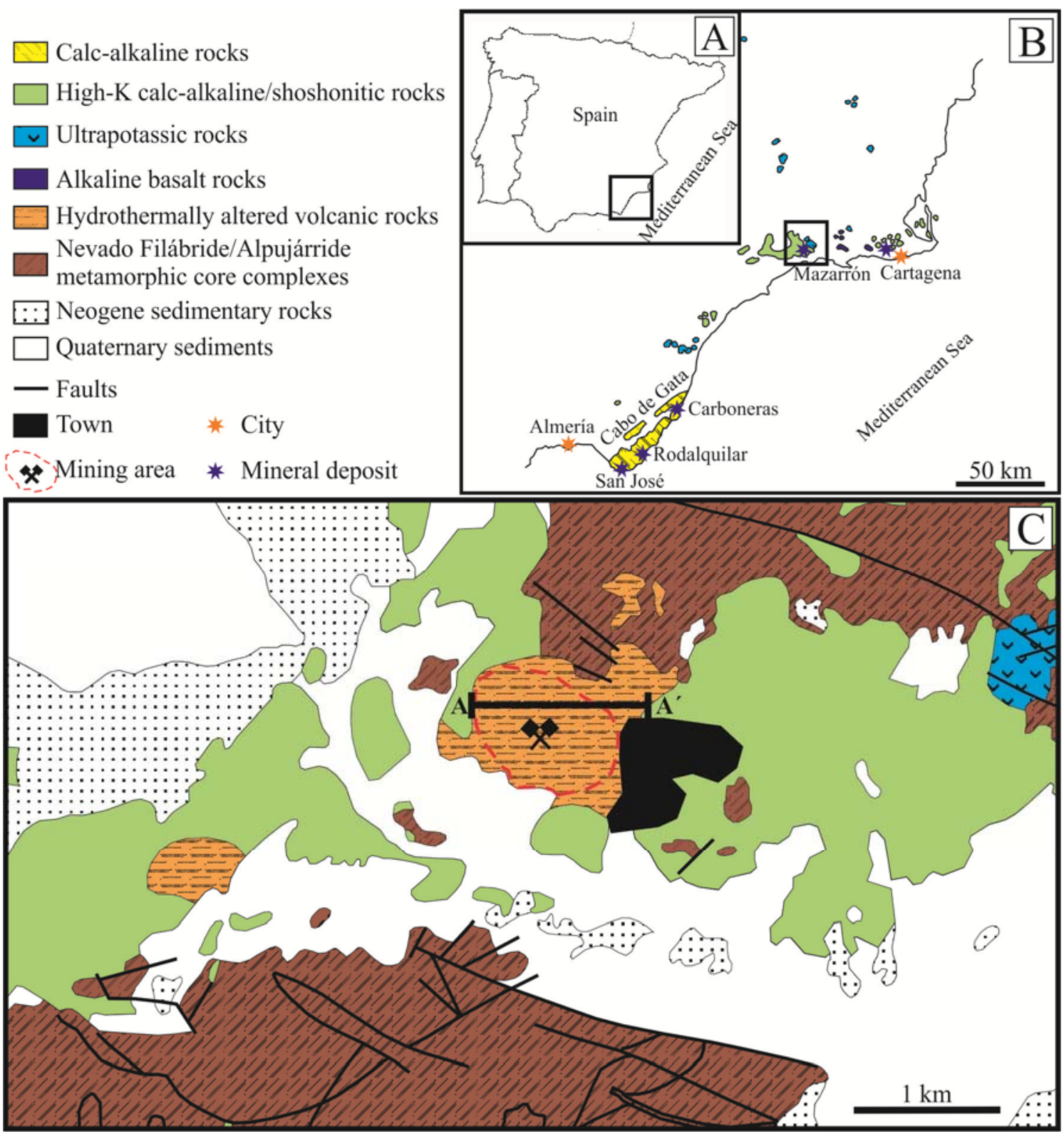

Figure 1: Geographical and geological framework of the Mazarrón deposit. (A) Position of Cabo de GataCartagena volcanic belt within the Iberian Peninsula (square). (B) Location of different types of magmatic suites in the volcanic belt (modified from López-Ruiz and Rodriguez-Badiola, 1980). The location of the Mazarrón deposit is marked with a square. (C) Geological map of the Mazarrón area (modified from Espinosa et al., 1974). 
The calc-alkaline and to a lesser extent the high- $\mathrm{K}$ calc-alkaline-shoshonitic series developed hydrothermal systems that affected the volcanic materials. In some cases, this hydrothermal alteration is associated with the formation of epithermal precious and base metal deposits such as the San José, Rodalquilar, Carboneras and Mazarrón deposits (Arribas and Tosdal, 1994; Arribas et al., 1995; Morales et al., 2000). Of these, the Zn-Pb-Cu-Ag Mazarrón ore deposit is the best example of mineralization linked to the high-K calc-alkalineshoshonitic volcanic episode.

There are other outcrops of volcanic rocks in the region, with no apparent relation to the deposits. These include the Pliocene alkaline basalts (Duggen et al., 2005; Cebria et al., 2008) located about $20 \mathrm{~km}$ east of Mazarrón. According to Oyarzun et al. (2011) a dike of these rocks crosses the outcrops of the Mazarrón deposit.

Volcanic rocks are within the sedimentary Neogene basin of Mazarrón-Lorca and also crosscut the underlying metamorphic rocks (amphibolites, gneisses, limestones, marbles, phyllites, quartzites, calcareous schists, sandstones, shales and evaporites; Espinosa Godoy et al., 1974) of the Paleozoic ( \pm Mesozoic) basement (belonging to the Nevado-Filábride and Alpujarride complexes, considered the main units of the metamorphic Betic core complex; Fig. 1). Vulcanites have a domatic structure and show porphyritic texture. They correspond to high $\mathrm{K}$ dacites and andesites, banakites and latites, with plagioclase, biotite, pyroxene (ortho- and clynopiroxene), sanidine, magnetite, ilmenite and quartz as the main phases. They often host enclaves, such as metapelitic xenolits (some of which are graphite-bearing) and igneous lithorelicts (Benito et al., 1999). The ${ }^{87} \mathrm{Sr}^{86} \mathrm{Sr}_{\mathrm{m}}$ ratio of these volcanic rocks ranges between 0.7087 and 0.7177 (Munksgaard, 1984; Benito et al., 1999; Turner et al., 1999). This suggests that the magmas originated from the lithospheric mantle previously contaminated by fluids derived from pelagic sediments (Benito et al., 1999), and/or contaminated by interaction with the basement. In particular, Triassic evaporites and limestones have less radiogenic strontium $\left({ }^{87} \mathrm{Sr} /{ }^{86} \mathrm{Sr}_{\mathrm{i}} \sim 0.707-0.708\right.$; Burke, 1982), while Paleozoic schists show highly radiogenic $\mathrm{Sr}\left({ }^{87} \mathrm{Sr} /{ }^{86} \mathrm{Sr}\right.$ up to 0.729 , Arribas et al., 1995b). The age of the anatexis and generation of this magma, and the age of the volcanism almost overlap. Thus $\mathrm{U} / \mathrm{Pb}$ data obtained by SHRIMP show ages of $9.6 \pm 0.2 \mathrm{Ma}, 9.1 \pm 0.2 \mathrm{Ma}$ (monacite) and $9.1 \pm 0.5 \mathrm{Ma}$ (zircon), while ${ }^{40} \mathrm{Ar} /{ }^{39} \mathrm{Ar}$ analyses on biotites give $8.9 \pm 0.6 \mathrm{Ma}$ and $8.8 \pm 0.2$ (Turner et al., 1999; Cesare et al., 2009).

\section{Samples and analytical techniques}

80 samples were collected from ore mineralization and hydrothermally altered host rocks. In order to characterize the alteration, 43 host rocks samples were analyzed using a Portable Infrared Mineral Analyser (PIMA; Integrated Spectronics Pty. Ltd.; Mineralogy and Petrology Department, University of Basque Country). The mineralogy was determined using an X-Ray diffractometer (Panalytical X'Pert PRO MPD, Mineralogy and Petrology Department,

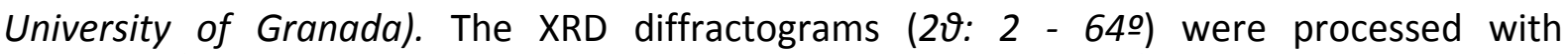
XPOWDER (Martin Ramos, 2004) and PANalytical X'Pert HighScore ${ }^{\circledR}$ (2004) software.

Selected samples $(n=35)$ were examined by transmitted and reflected light microscopy, and subsequently electronically scanned with EDX microanalyzer microscopy (ZEISS ${ }^{\circ}$ DSM 950 and LEO GEMINI-1530, at the Scientific Instrumentation Center, University of Granada) in order to obtain the relevant backscattered and element map images. 
All the stable isotopic studies were carried out at the Scottish Universities Environmental Research Centre (SUERC; East Kilbride, Scotland). A total of 79 sulfide, sulfate and carbonate samples were analyzed using a combination of laser and conventional techniques (Table 1). Sulfur was extracted from sulfide and sulfate samples for conventional isotope analyses according to procedures proposed by Robinson and Kusakabe (1975) and Coleman and Moore (1978). The in situ sulfide laser combustion method (Kelley and Fallick, 1990; Wagner et al., 2002) was used on polished sections in order to detect isotopic heterogeneities at a microscopic scale. In both cases, the gases that were released were analyzed on a VG Isotech SIRA $\|{ }^{\circledast}$ mass spectrometer. Oxygen from three barite samples was converted to $\mathrm{CO}_{2}$ according to Hall et al. (1991). Seven dolomite and one siderite samples were also converted into $\mathrm{CO}_{2}$ by reaction with phosphoric acid at $100^{\circ} \mathrm{C}$. The $\mathrm{CO}_{2}$ produced in both cases was analyzed on a VG SIRA $10^{\circledR}$ mass spectrometer. Analytical raw data were corrected using standard procedures (Craig, 1957). Isotope data were reported in standard -notation as per mil (\%o) deviations relative to the Vienna Canyon Diablo Troilite, Vienna Standard Mean Ocean Water and PeeDee Belemnite standards. The error of reproducibility, $1 \sigma$, based on complete analysis of internal standards was $\pm 0.1 \%$ o for $\delta^{13} \mathrm{C}, \pm 0.2 \%$ ofor $\delta^{34} \mathrm{~S}$ and $\pm 0.2 \%$ o $\delta^{18} \mathrm{O}$.

$\mathrm{Rb}-\mathrm{Sr}$ isotopic analyses were performed at the Scientific Instrumentation Center, at the University of Granada. Four carbonate, two barite, one jarosite and six hydrothermally altered rock samples were dissolved using standard techniques for $\mathrm{Rb}-\mathrm{Sr}$ isotopic analysis, which was performed in an MAT $262^{\circ}$ thermal ionization mass spectrometer, with an RPQ high sensitivity filter and a multicollector. The ${ }^{87} \mathrm{Sr} /{ }^{86} \mathrm{Sr}$ normalization value was ${ }^{87} \mathrm{Sr} /{ }^{86} \mathrm{Sr}=8.375209$ and the reproducibility under successive analyses of the NBS-987 dissolved standard was better than $0.0007 \%(2 \sigma)$.

Fluid inclusions trapped in carbonates, sphalerite and quartz from the veins were studied at the Department of Mineralogy and Petrology at Granada University in doubly polished thin-sections of about $100 \mu \mathrm{m}$ thick using a Linkam THMSG 600 heating-freezing stage. Results are reproducible to $\pm 0.5 \circ \mathrm{C}$ and $\pm 5 \circ \mathrm{C}$ for freezing and heating runs, respectively. Complementary qualitative analyses using a RENISHAW Confocal Raman microscope (SGlker lab, University of Basque Country) were performed for detection of $\mathrm{CO}_{2}$ or $\mathrm{CH}_{4}$ in selected fluid inclusions.

The K-Ar radiometric dating was performed in the Servicio Nacional de Geología y Minería (SENARGEOMIN), in Santiago (Chile). In this case two samples of illite concentrate of ca. <2 $\mu \mathrm{m}$ particle size fraction were prepared for analysis using an AEI MS-10-S mass spectrometer, with $180^{\circ}$ sector, a fixed magnetic field and high vacuum extraction lines.

Table 1. Stable and radiogenic isotope analyses of separated minerals from the Mazarrón deposit. (*) Analyses performed using the in situ laser combustion method. (**) $\delta 180$ of fluid was calculated on the basis of a temperature range of $190-260^{\circ} \mathrm{C}$, obtained in the fluid inclusion study.

\begin{tabular}{llr|llr}
\multicolumn{5}{c}{ Sulfides } \\
\hline SAMPLE & MINERAL & $\boldsymbol{\delta}^{\mathbf{3 4}} \mathbf{S}$ & SAMPLE & MINERAL & $\boldsymbol{\delta}^{\mathbf{3 4}} \mathbf{S}$ \\
MZR-SA-5 & Pyrite & -2.9 & M-7 & Galena & 8.5 \\
M-6 & Pyrite & 7.5 & M1 & Galena & 5.7 \\
MZR-893-B-1 & Pyrite & 22.8 & M-17 & Galena & 9.7 \\
M-17 & Pyrite & 21.5 & $872-B-2(*)$ & Galena & 8.0 \\
M-7 & Pyrite & 3.9 & $872-B-2(*)$ & Galena & 8.2 \\
S-872 & Pyrite & 15.8 & $872-B-2(*)$ & Galena & 9.4 \\
MZR-15 & Pyrite & $872-B-3(*)$ & Galena & 10.7 \\
872-B-2 $\left(^{*}\right)$ & Pyrite & 8.9 & $1-1(*)$ & Galena & 8.5
\end{tabular}




\begin{tabular}{|c|c|c|c|c|}
\hline 872-B-2 (*) & Pyrite & 10.1 & $1-1(*)$ & Galena \\
\hline 872-B-3 (*) & Pyrite & 12.3 & $1-1(*)$ & Galena \\
\hline $1-2(*)$ & Pyrite & 16.5 & $1-2(*)$ & Galena \\
\hline 893-BX-1 (*) & Pyrite & 26.7 & $1-2(*)$ & Galena \\
\hline 893-BX-1 (*) & Pyrite & 24.6 & 893-BX-1 (*) & Galena \\
\hline 893-BX-1 (*) & Pyrite & 24.4 & M-3 & Galena \\
\hline 893-BX-1 (*) & Pyrite & 21.5 & M-3 & Sphalerite \\
\hline 893-B-2 (*) & Pyrite & 28.4 & M-3 & Sphalerite \\
\hline 893-B-2 (*) & Pyrite & 25.5 & M-7 & Sphalerite \\
\hline MZR-SA-853-B & Pyrite & -0.1 & 872-B-2 (*) & Sphalerite \\
\hline 893-BX-1 (*) & Marcasite & 24.1 & MZR-SA-853-B & Sphalerite \\
\hline 893-BX-1 (*) & Marcasite & 28.0 & $1-1(*)$ & Sphalerite \\
\hline 893-BX-1 (*) & Marcasite & 27.9 & $1-2(*)$ & Sphalerite \\
\hline 893-BX-1 (*) & Marcasite & 28.3 & 893-BX-1 (*) & Sphalerite \\
\hline 893-BX-1 (*) & Marcasite & 25.8 & M-1 & Sphalerite \\
\hline 893-B-2 (*) & Marcasite & 25.6 & M-1 & Sphalerite \\
\hline 893-B-2 (*) & Marcasite & 26.7 & M-6 & Sphalerite \\
\hline M-7 & Chalcopyrite & 4.9 & M-893-B-1 & Sphalerite \\
\hline MZR-SA-853-B & Galena & 6.4 & M-893-B-1 & Sphalerite \\
\hline M-893-B-1 & Galena & 9.8 & & \\
\hline
\end{tabular}

\section{Sulfates}

\begin{tabular}{|c|c|c|c|c|}
\hline SAMPLE & MINERAL & $\delta^{18} \mathbf{O}_{\text {SO4 }}$ & $\left({ }^{87} \mathrm{Sr} /{ }^{86} \mathrm{Sr}\right)_{\mathrm{i}}$ & $\delta^{34} \mathbf{S}$ \\
\hline MZR-13 & Barite & 16.6 & 0.7142 & 53.9 \\
\hline MZR-13 & Barite & 16.6 & 0.7142 & 53.5 \\
\hline MZR-SA-A & Barite & 11.5 & 0.7143 & 14.8 \\
\hline MZR-SA-B & Barite & & & 18.5 \\
\hline SAMPLE & MINERAL & $\delta^{18} \mathbf{O}_{\text {SO4 }}$ & $\left({ }^{87} \mathrm{Sr} /{ }^{86} \mathrm{Sr}\right)_{\mathrm{i}}$ & $\delta^{34} \mathrm{~S}$ \\
\hline MZR-11 & Alunite & 6.7 & 0.7155 & 1.4 \\
\hline MZR-8-A-1 & Jarosite & & & 12.7 \\
\hline MZR-8-A-2 & Jarosite & 3.2 & & 14.0 \\
\hline MZR-8-B-A & Jarosite & & & 2.4 \\
\hline MZR-8-B-B & Jarosite & & & 2.8 \\
\hline MZR-12-A & Jarosite & 13.2 & 07139 & 3.6 \\
\hline MZR-12-C & Jarosite & 12.5 & 0.7139 & 4.9 \\
\hline
\end{tabular}

\section{Mazarrón ore deposit}

The Mazarrón veins were first mined during the Roman Empire and were intensively exploited above all from 1880 to 1960, for $\mathrm{Pb}, \mathrm{Cu}$ and $\mathrm{Ag}$. At their peak, ore grades reached up to $10 \% \mathrm{~Pb}, 5 \% \mathrm{Zn}$ and $1500 \mathrm{~g} / \mathrm{t} \mathrm{Ag}$ (Manteca et al., 2005). A mining exploration survey by Navan Resources SA estimated reserves of $11 \mathrm{Mt}$ with $2.6 \% \mathrm{Zn}, 0.6 \% \mathrm{~Pb}$ and $17 \mathrm{~g} / \mathrm{t} \mathrm{Ag}$ (Rodríguez and Hidalgo, 1997).

\subsection{Ore mineralization}

The ores appear filling open spaces in the subvertical vein system (along N120E direction), occasionally with an irregular stockwork structure (Christmas tree-like morphology) that crosscuts the volcanic dome close to the town of Mazarrón (Fig. 2). The veins, which have a lateral extension of up to $500 \mathrm{~m}$ and a depth of about $650 \mathrm{~m}$, dip westwards, becoming vertical at depth. The thickness of these veins ranges from millimeters to meters, though at depth they usually merge to reach a bonanza zone of up to 15 meters thick (Corbella, 1969). Some drill holes made for water extraction in the area have crossed metamorphic rocks in the basement containing a noticeable dissemination of pyrite. However, away from the deposit, the same metamorphic rocks do not normally have pyrite dissemination. 


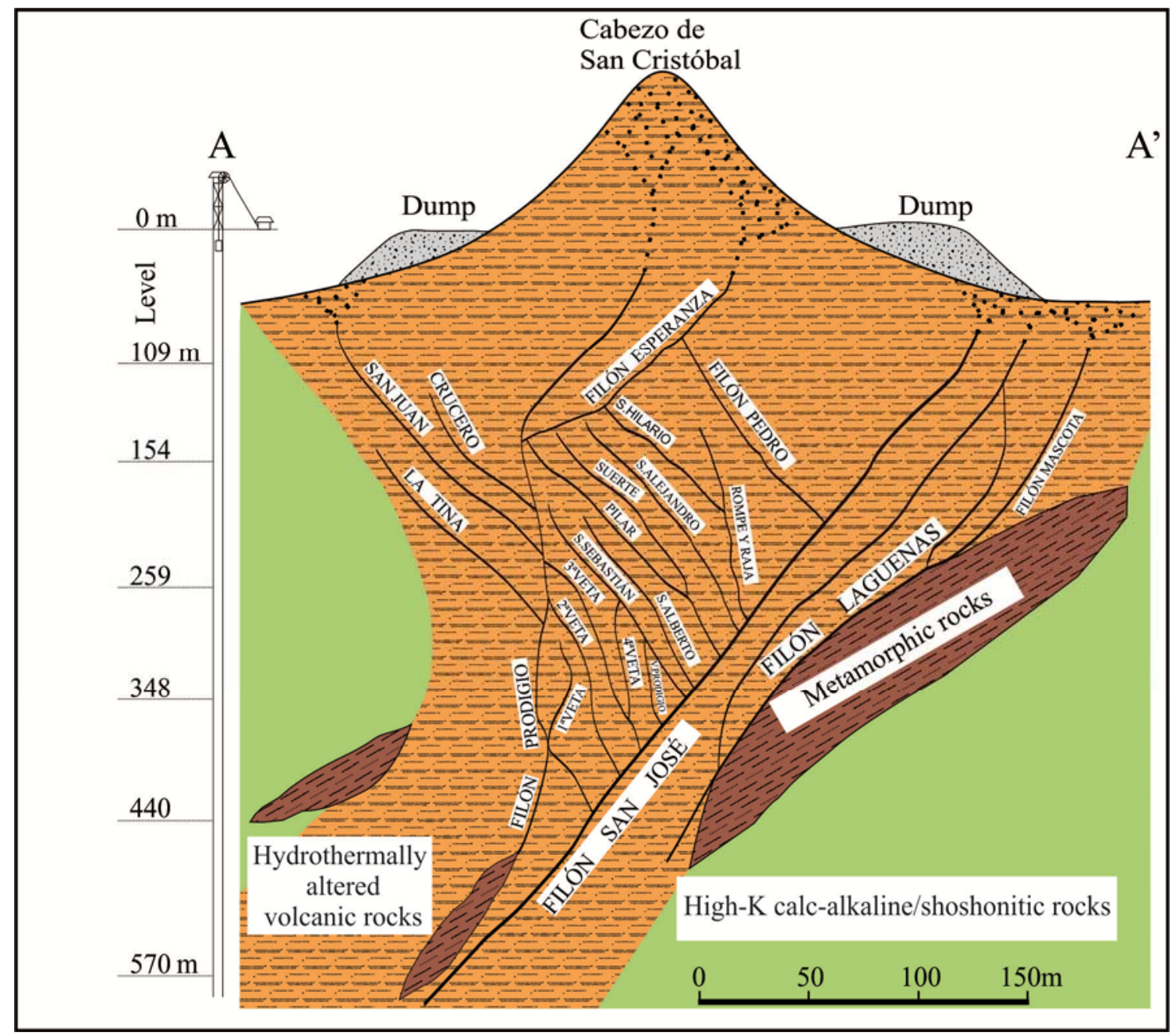

Figure 2: View at depth of the Mazarrón mineralization system (based on old mining information; GuillénRiquelme, 1997). The A-A' section is the same section shown in Figure 1.

Petrographic analyses of the Mazarrón $\mathrm{Zn}-\mathrm{Pb}-\mathrm{Cu}-\mathrm{Ag}$ mineralization show that ores are characterized by sulfides filling open spaces, generally dominated by crustiform bands and collomorphic and cockade textures. Two main mineral associations can be distinguished: a) Fe-sulfide mineral association with pyrite and marcasite as the major phases, with smaller quantities of pyrrhotite; b) polymetallic mineral association characterized by sphalerite, galena and magnetite with small quantities of chalcopyrite, arsenopyrite and tetrahedritetennantite. According to Arana et al. (1993) polymetallic mineral association appears in the shallowest area (sphalerite mainly at depths of less than $100 \mathrm{~m}$ and galena at depths of less than $500 \mathrm{~m}$ ), while Fe-sulfide mineral association becomes the dominant association at greater depths.

The mineralogical and textural study of these minerals is synthesized in the paragenetic sequence shown in Figure 3. The most common sulfide is pyrite, which occurs throughout the ore mineralization sequence. Early pyrite is coarse-grained and occurs, rarely, well crystallized in a euhedral cube-shaped habit. Later pyrite on the other hand is fine-grained and occurs together with marcasite showing banded collomorphic morphologies (Fig. 4A). Sphalerite appears as anhedral crystals or forming fine-banded red-brown encrustations, 
with a later colourless phase (Fig. 4B). Galena, associated to sphalerite, appears as euhedral cubic crystals, usually in the form of overgrowths or infilling fractures in sphalerite and more rarely as tabular crystals. The last sulfide precipitate was chalcopyrite, which commonly occurs filling cavities of previous sulfides (sphalerite, galena) or as fine bleb-like inclusions in sphalerite ("chalcopyrite disease"; Fig. 4C). Other minor sulfides, such as fahlore (tetrahedrite-tennantite) and arsenopyrite, appear as minute microcrystals inside the galena (Fig. 4D), showing above all crystallographic orientation. Finally, magnetite (locally up to $40 \%$ modal) crystals appear associated with sphalerite and galena (Fig. 4E) as well as with carbonates (mainly dolomite and subordinate siderite), adopting in these cases skeletal shapes; in the former, crystals show a well-developed concentric zonation pattern, based on the variation of $\mathrm{V}$ contents.

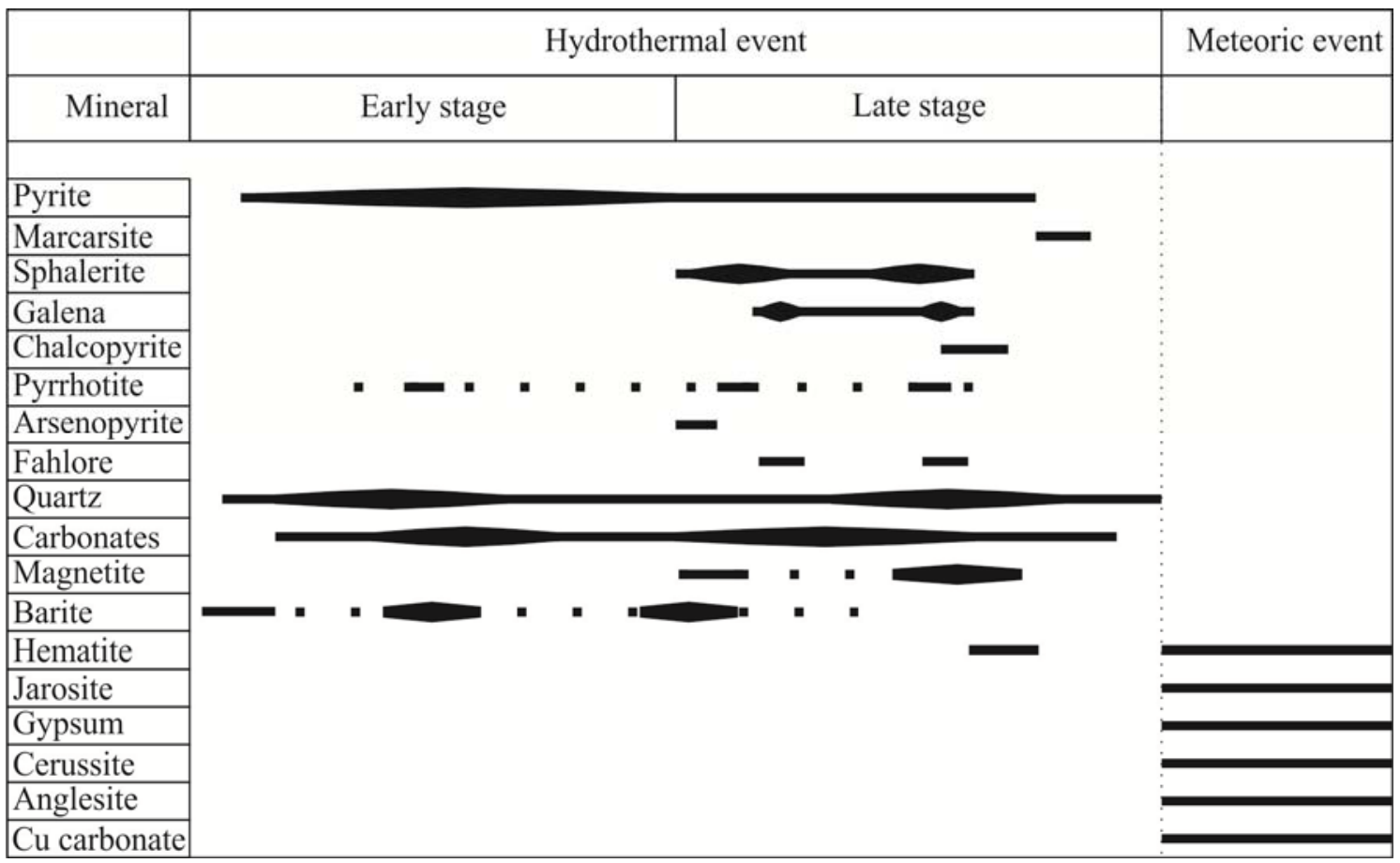

Figure 3: Paragenetic sequence of minerals observed in vein mineralizations of Mazarrón, according to structural and textural characteristics.

Carbonate is the most abundant mineral in the gangue, with subordinate barite and quartz. XRD data of the carbonates indicate the predominance of dolomite with smaller amounts of siderite. The SEM study reveals complex carbonate chemistry due to concentric zonation, defined by variations in $\mathrm{Fe}, \mathrm{Mg}, \mathrm{Ca}, \mathrm{Zn}$, and $\mathrm{Mn}$ contents (Fig. 4F). Although the carbonates occur throughout the mineralization, they are mainly concentrated in the late ore stage as cement, and occasionally result in monomineralic veins. Barite occurs early in the paragenetic sequence associated with earlier pyrite, and also forming late monomineralic veins. Quartz is a ubiquitous phase in all mineralization stages, although it is most common in the polymetallic association.

Alunite, partially converted into jarosite, appears close to shallow zones filling abundant veins, of up to $10 \mathrm{~cm}$ in size, or disseminated in altered rocks, especially in zones with advanced argillic alteration. In addition to jarosite, the most common minerals found in near 
surface supergene zones are hematite, goethite, Mn-bearing oxyhydroxides, cerussite, anglesite, gypsum, malachite and azurite.

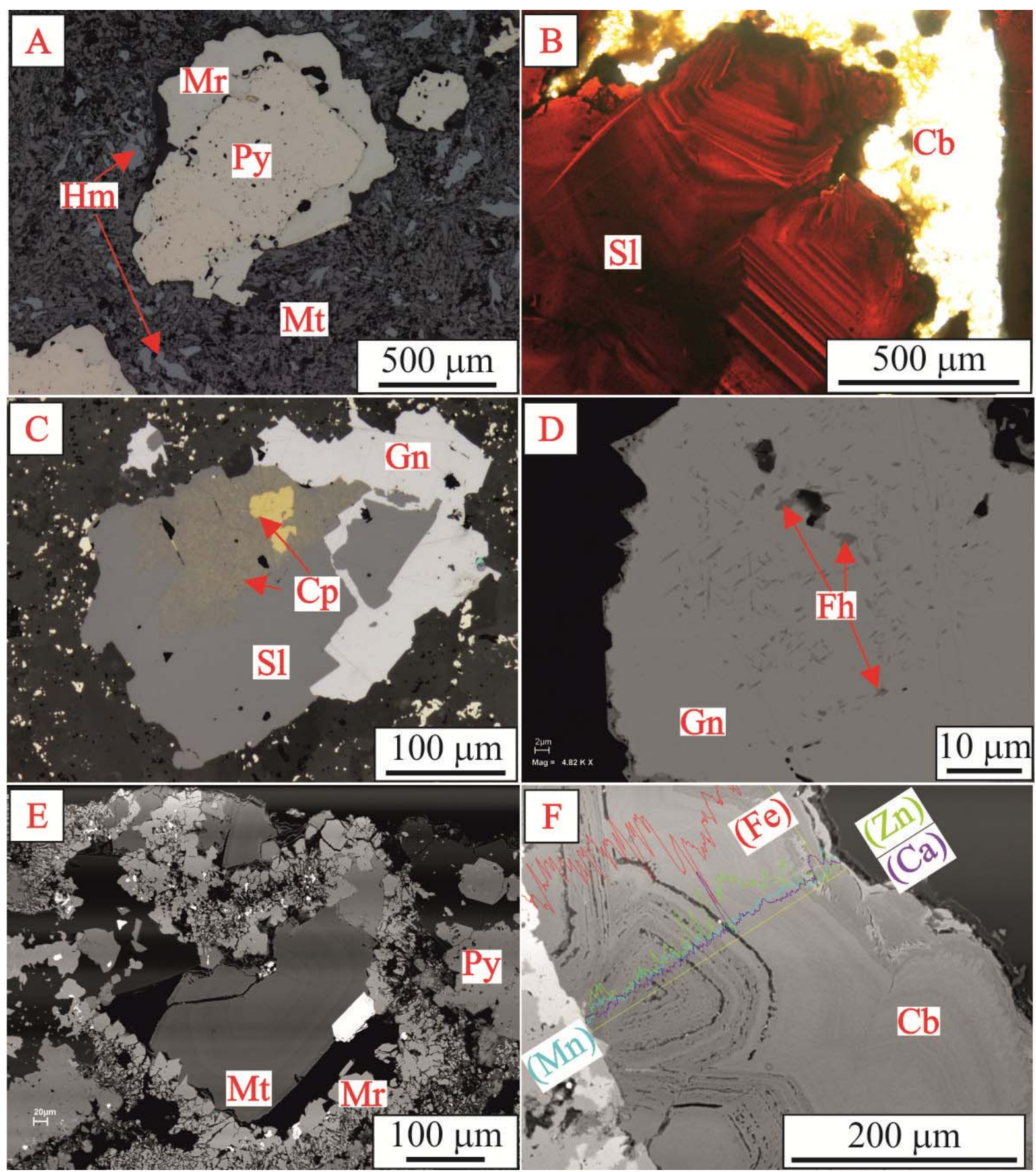

Figure 4: Different images of the mineralogy of the mineralization. (A) Marcasite cover around pyrite crystals, in carbonated matrix, partially replaced by magnetite and hematites (reflected microscopy). (B) Zoned sphalerite crystals with carbonates (transmitted microscopy). (C) Sphalerite crystal, partially covered by galena, with substantial replacement by chalcopyrite (chalcopyrite disease) (reflected microscopy). (D) Tennantite-tetrahedrite crystal inclusions inside galena (electronic microscopy). (E) Well developed and fracturated magnetite crystal, clearly zonated, associated with iron sulfides (pyrite and marcasite). $(F)$ Carbonate crystal, with clear zonation in fine levels, caused by chemical changes: $F e=i r o n, Z n=z i n c$, $C a=$ calcium, $M n=$ manganese. Abbreviations: $C b=$ carbonates, $C p=$ chalcopyrite, $F h=$ fahlore, Gn=Galena, $H m=$ hematite, $M r=$ marcasite, $M t=$ magnetite, $P y=$ pyrite, $S l=$ sphalerite . 


\subsection{Hydrothermal alteration}

The deposit is linked to a hydrothermal system developed during the Miocene in volcanic rocks, with the formation of areas of ore disseminations and veins accompanied by intense hydrothermal alteration, mainly in the vicinity of fractures through which hydrothermal fluids have circulated. These altered rocks are arranged around the Mazarrón veins or veins systems and may be classified in terms of their mineralogy and textures as follows:

1. Silicification. Typically consists of nearly complete transformation of the volcanic rocks into quartz, which appears as small patches near the veins or as variably silicified zones associated with high vein density. In these rocks the former volcanic phenocrysts only remain as holes, resulting in a typical vuggy silica texture.

2. Advanced argillic alteration. This is characterized by the replacement of all feldspar phenocrysts by kaolinite. In the case of pyroxenes and biotite phenocrysts, kaolinite is accompanied by Fe-Al bearing sulfates, and particularly by jarosite (Fig. 5A). Near the mineralized veins there are areas of very intense alteration, in which the volcanic rocks have been completely transformed into massive alunite-quartz assemblage (Fig. 5B).

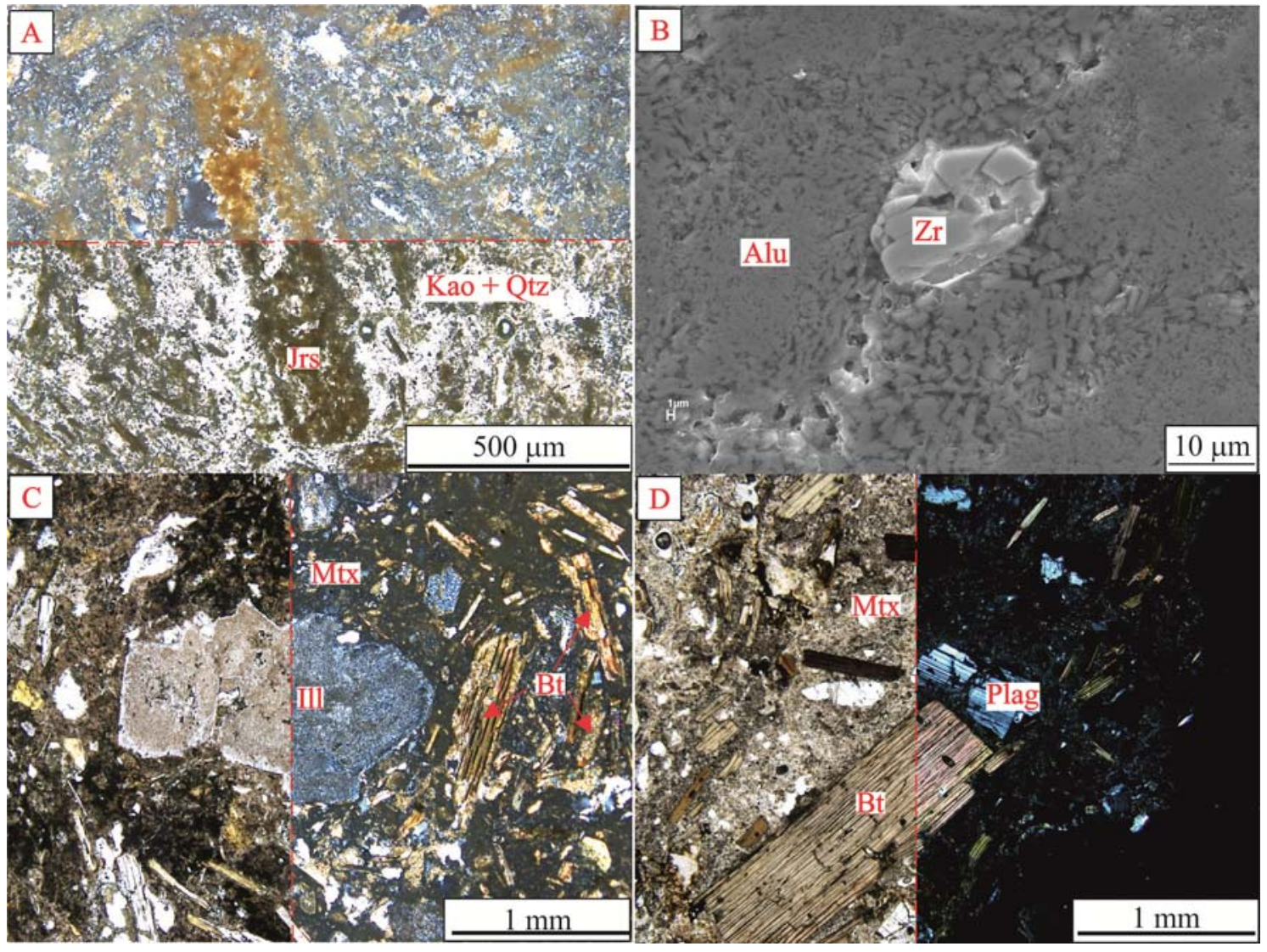

Figure 5: Different images of hydrothermally altered rock. (A) Advanced argillic alteration with the matrix completely altered to a mixture of kaolinite and quartz, and biotite phenocrystals transformed to jarosite. (B) Polished rock section of alunitized volcanic rock, in which only primary zircon crystal remains (BSE image in VPSEM). (C) Argillic alteration, with complete illitizated plagioclases and biotites altered to jarosite, in a moderately altered matrix. (D) Less altered rock (propylitic alteration) with unaltered phenocrystals and matrix. Dotted red line separates image taken with polarized light from that with cross-polarized light (right part in case of $A$ and B, and upper part in case of C). Abbreviations: Alu=alunite, Bt=biotite, Ill=illite, $J r s=$ jarosite, $K a o=$ kaolinite, Mtx=matrix, Plag=plagioclase, $Q t z=q u a r t z, Z r=z i r c o n$. 
3. Argillic alteration. Plagioclase is replaced by illite (Fig. 5C) while biotite, and in some cases pyroxenes, are partially replaced by jarosite and minor alunite and Fe-oxides. These sulfates also appear filling cavities and veins. Most of the volcanic matrix has been transformed almost entirely into an intricate assemblage of kaolinite, illite, and quartz.

4. Propylitic alteration. The main volcanic texture is conserved (Fig. 5D), although significant transformation to illite can be observed in some minerals (complete transformation in pyroxenes, almost complete in plagioclases and a partial start in biotites). In this zone, rocks are crosscut by carbonate veins. Other typical minerals in this alteration zone, such as chlorite and epidote, are absent.

The transition to non-hydrothermally altered rock (with regional/meteoric alteration) is indicated by the presence of less intense illitization, limited to partial transformation of pyroxenes and incipient in the rims of plagioclase phenocrysts.

\subsection{Fluid inclusions}

The fluid inclusions we studied in the quartz-carbonate veins (mainly in sphalerite, quartz, dolomite and barite), are two-phase liquid-vapour inclusions, with an estimated degree of filling of 0.85 to 0.95 (\% vol. of liquid $\mathrm{H}_{2} \mathrm{O}$ ), ranging in size from 5 to $20 \mu \mathrm{m}$. The fluid inclusion petrography, based on the FIA approach (fluid inclusion assemblage) indicates random three-dimensional distribution of inclusions in the core of the crystals or located on early healed micro-fractures. Fluid inclusions belonging to the earliest FIA exhibit sub-irregular to spherical or negative crystal shapes. These inclusions have been considered as primary or pseudo-secondary based on the criteria summarized by Roedder (1984).

The microthermometric study of fluid inclusions shows first melt temperatures (Te) of between -40 and $-50 \circ \mathrm{C}$ indicating that the fluids could be represented by the system $\mathrm{H}_{2} \mathrm{O}-$ $\mathrm{NaCl}-\mathrm{CaCl}_{2}$ (Shepherd et al., 1985). During freezing, no changes in the vapor phase were observed, suggesting that the presence of other gases such as $\mathrm{CO}_{2}$ in the vapor phase is negligible. MicroRaman analyses of selected inclusions did not detect $\mathrm{CO}_{2}$ or $\mathrm{CH}_{4}$. Ice melt temperatures ranging from -15.0 to $-7.7{ }^{\circ} \mathrm{C}$ ( -8.6 to $-8.3^{\circ} \mathrm{C}$ for fluid inclusions in sphalerite, 12.2 to -8.3 o $\mathrm{C}$ for fluid inclusions in quartz, and -15.0 to -7.7 으 for fluid inclusions in dolomite) indicate salinities between 12 and 18 wt. \% $\mathrm{NaCl}$ eq. Homogenization temperatures indicate that hydrothermal fluids mainly deposited ore and gangue minerals within a range of 190 to $260^{\circ} \mathrm{C}$ (Fig. 6). The graph plotting the homogenization temperature against salinity suggests that there is a slightly positive correlation between both magnitudes (Fig. 6). We interpret these data as a mixture of two inferred fluids: (i) a hydrothermal fluid (F1) with low salinity (1-3 wt. \% $\mathrm{NaCl}$ eq) and temperature $\left(100^{\circ} \mathrm{C}\right)$, which we interpret as surface waters, and (ii) a dominant ore fluid (F2) with moderate salinity (16-21 wt. \% $\mathrm{NaCl}$ eq) and a higher temperature (200-340ㄷ). According to geochemical evidence, this second fluid results from mixing between the basinal ( $28 \mathrm{wt} . \% \mathrm{NaCl}$ eq and $40 \circ \mathrm{C}$ ) and magmatic fluids (10 wt. \% $\mathrm{NaCl}$ eq and 500 으). 


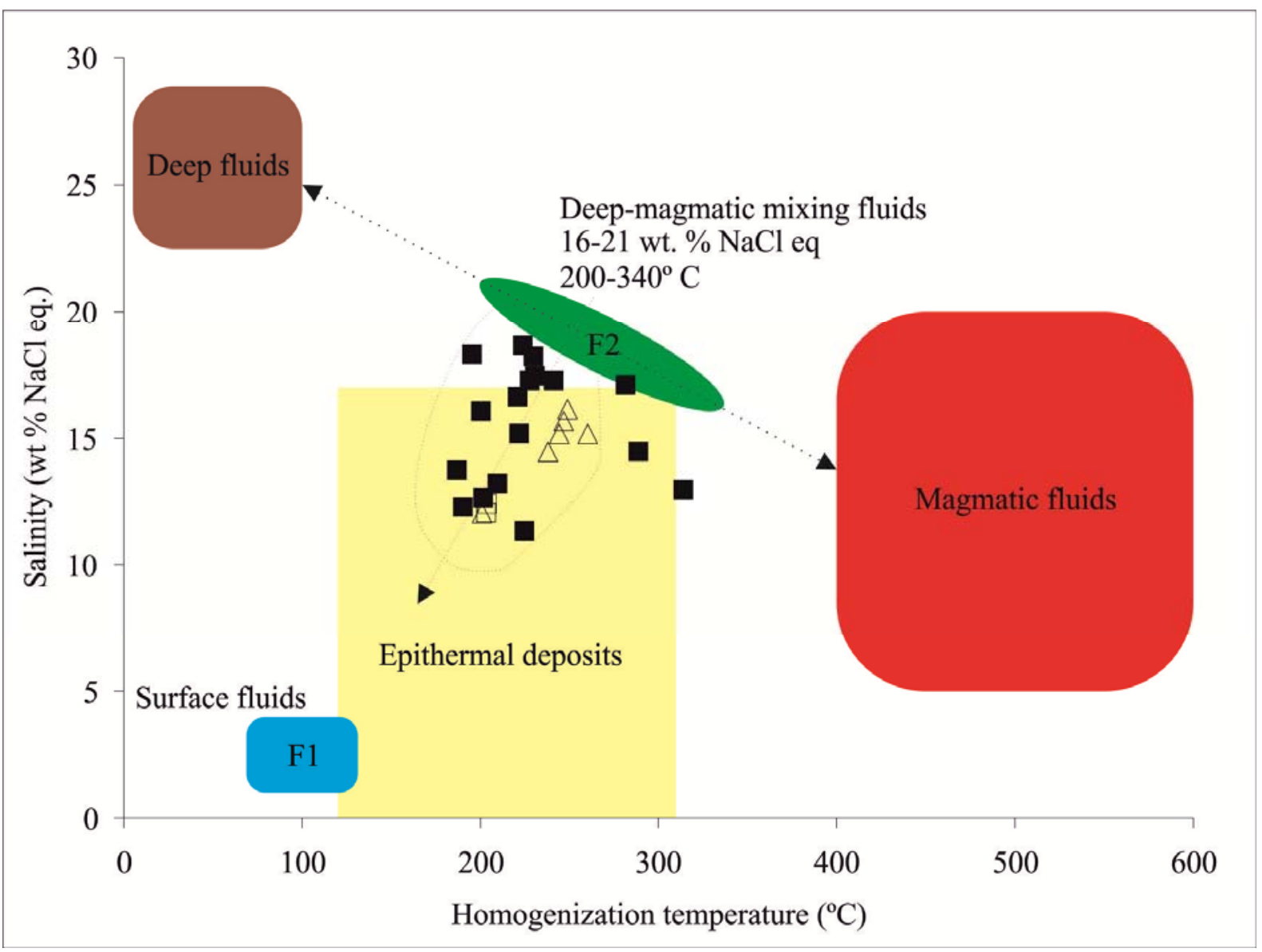

Figure 6: Salinity (wt \% NaCl equiv.) vs. homogenization temperature $\left({ }^{\circ} \mathrm{C}\right.$ ) in fluid inclusions in carbonates (solid squares), sphalerite (empty squares) and quartz (empty triangles). Blue (modified from Dietrich and Kalle, 1963) and green boxes mark hypothetical extreme fluids (F1 and F2) that when mixed give the observed trend. The yellow box marks the features of the epithermal deposits (Bodnar et al., 2014). Red (modified from Hedenquist and Lowenstern, 1994) and brown boxes represent fluids which when mixed create F2 fluid.

\subsection{Stable and radiogenic isotope geochemistry}

Sulfide sulfur analyses revealed the existence of a wide range of $\delta^{34} S$ values from $-2.9 \%$ o to $+28.4 \%$ o (Fig. 7). While the main base sulfides (sphalerite, galena and chalcopyrite) show a relatively homogeneous sulfur signature $\left(\delta^{34} S\right.$ from +3.7 to $\left.+12.3 \%\right)$, pyrite and marcasite have very heterogeneous ones $\left(\delta^{34} \mathrm{~S}\right.$ between -2.9 and $+28.4 \%$ ). The study of the iron sulfides reveals a rough correlation between sulfur isotopic data and the situation in paragenetic sequence. Early coarse-grained pyrite shows the most depleted sulfur ratios (up to $-2.9 \%$ ). Late collomorphic pyrite and marcasite, which describe clear enrichment trends (Fig. 8), are limited to heavier $\delta^{34}$ S values: +22.8 to $+28.4 \%$.

Barite supplied very distinctive $\delta^{34} S$ values: between +14.8 to $+18.5 \%$ and heavier data (two results around $+53.9 \%$ ). The isotope ratios for Fe-Al sulfates are relatively depleted in the case of alunite $\left(+1.4 \%\right.$ o $\left.\delta^{34} S\right)$, with higher values in jarosite $\left(\delta^{34} S\right.$ between +2.4 and +4.9 $\delta^{34} \mathrm{~S}$ and between +12.7 and $+14.0 \%$ o). Barite shows $\delta^{18} \mathrm{O}_{\text {sO4 }}$ values of $+11.5 \%$ o and $+16.6 \%$ o. In this case, $\delta^{18} \mathrm{O}$ and $\delta^{34} \mathrm{~S}$ correlate positively. Alunite shows $\delta^{18} \mathrm{O}_{\mathrm{SO} 4}$ of $+6.7 \%$ o while the value for jarosite is $+3.2 \%$ and between +12.5 and $+13.2 \%$. In the case of Fe-Al sulfates, we found inverse correlation between $\delta^{34} \mathrm{~S}$ and $\delta^{18} \mathrm{O}$. 


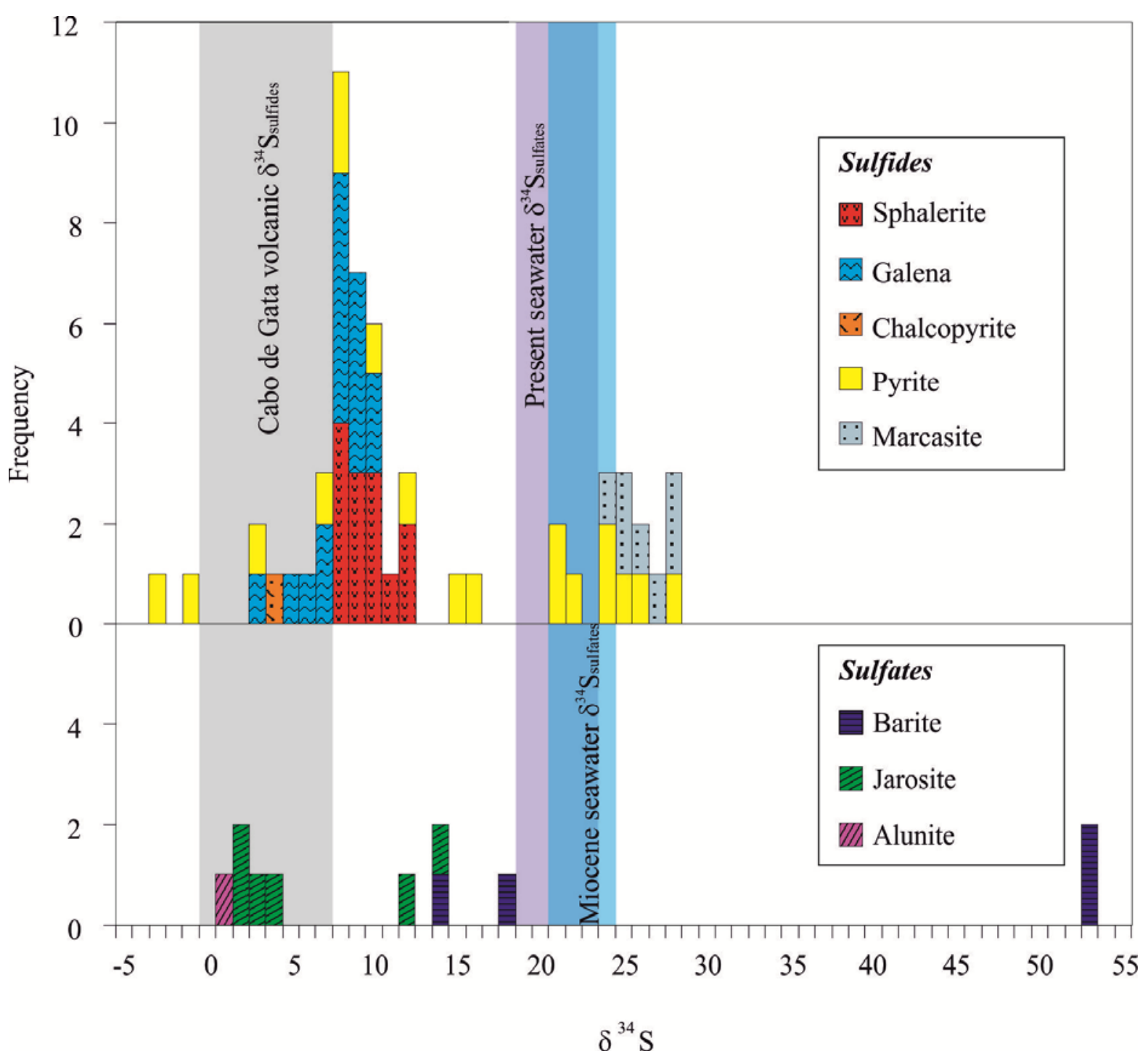

Figure 7: Histogram of $\delta^{34} S$ data obtained by conventional and in situ laser-combustion techniques of sulfides and sulfates from the Mazarrón deposit. Superimposed on the histogram are shadowed areas that mark the isotopic range for volcanic sulfides from the Cabo de Gata calc-alkaline rocks (Arribas et al., 1995) and for sulfates from the Miocene and from today (Claypool et al., 1980).

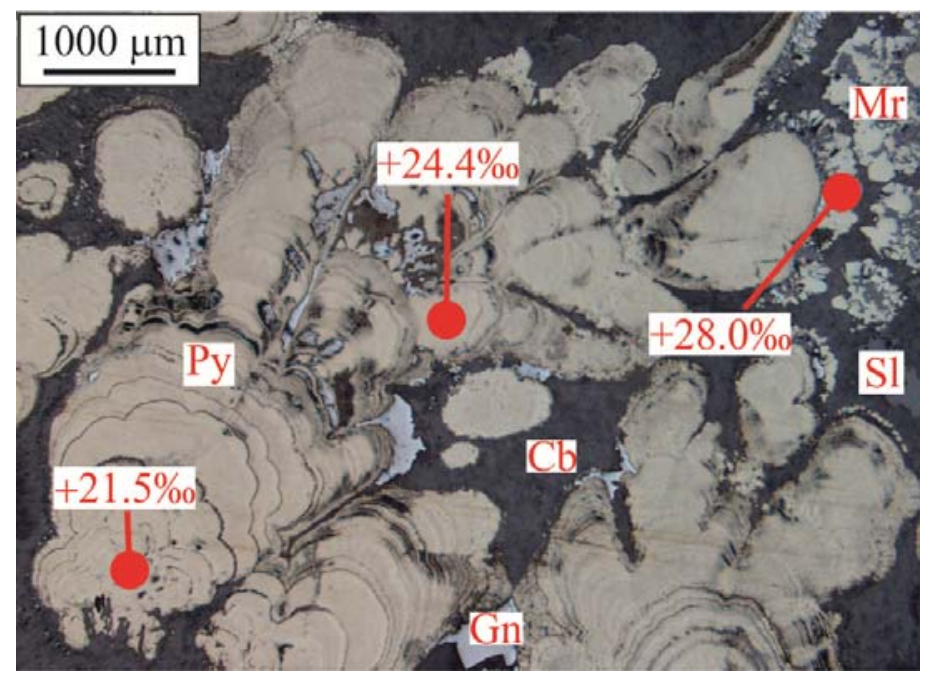

Figure 8: Photomicrograph (reflected light) of collomorphic pyrite (Py) overgrown by marcasite (Mr), galena (Gn), sphalerite (Sl) and carbonates (Cb), plus the sulfur isotopic signature. The $\delta^{34} S$ values of sulfides have been obtained by in situ laser combustion analysis and suggest an enriched sulfur isotopic trend. 
Quartz from the gangue has a relatively homogeneous isotopic composition, with $\delta^{18} \mathrm{O}_{\mathrm{Qtz}}$ between +12.6 and $+14.4 \%$. Calculated $\delta^{18} \mathrm{O}_{\text {fluid }}$ of parent hydrothermal fluid (according to Matsuhisa et al., 1979) equations, using the temperature estimated in the fluid inclusions study $(190-260 \circ \mathrm{C})$, indicate values of between +0.3 and $+6.0 \%$. Carbonates show a wide $\delta^{18} \mathrm{O}_{\mathrm{Cb}}$ range from +11.4 to $+23.1 \%$, with most values around $+20.0 \%$ o (Fig. 9). Calculated $\delta^{18} \mathrm{O}_{\text {fluid }}$ at temperatures of between 190 and 260ㅇ (using Carothers et al., 1988 and Zheng, 1999 fractionation factors) reveal a very wide fluid isotopic range from +0.8 to $+15.8 \%$ o (Table 1$)$. In contrast, carbon isotopes are generally more homogeneous $\left(\delta^{13} \mathrm{C}\right.$ from -7.7 to $11.2 \%$, with two values around 0\%; Fig. 9).

Figure 9: $\delta^{13} C_{P D B} \quad v s$. $\delta^{18} O_{S M O W}$ binary diagram of carbonates from the Mazarrón deposit. Shallow zones show values for biogenic origin (Vogel, 1993), basement of the zone (Alt et al., 2012), magmatic-mantle (Javoy et al., 1986; Deines et al., 1991; Cartigny et al., 1998), marine carbonates (Ohmoto and Rye, 1979) and $C$ values of current $\mathrm{CO}_{2}$ signature with deep origin (Pérez del Villar et al., 1998).

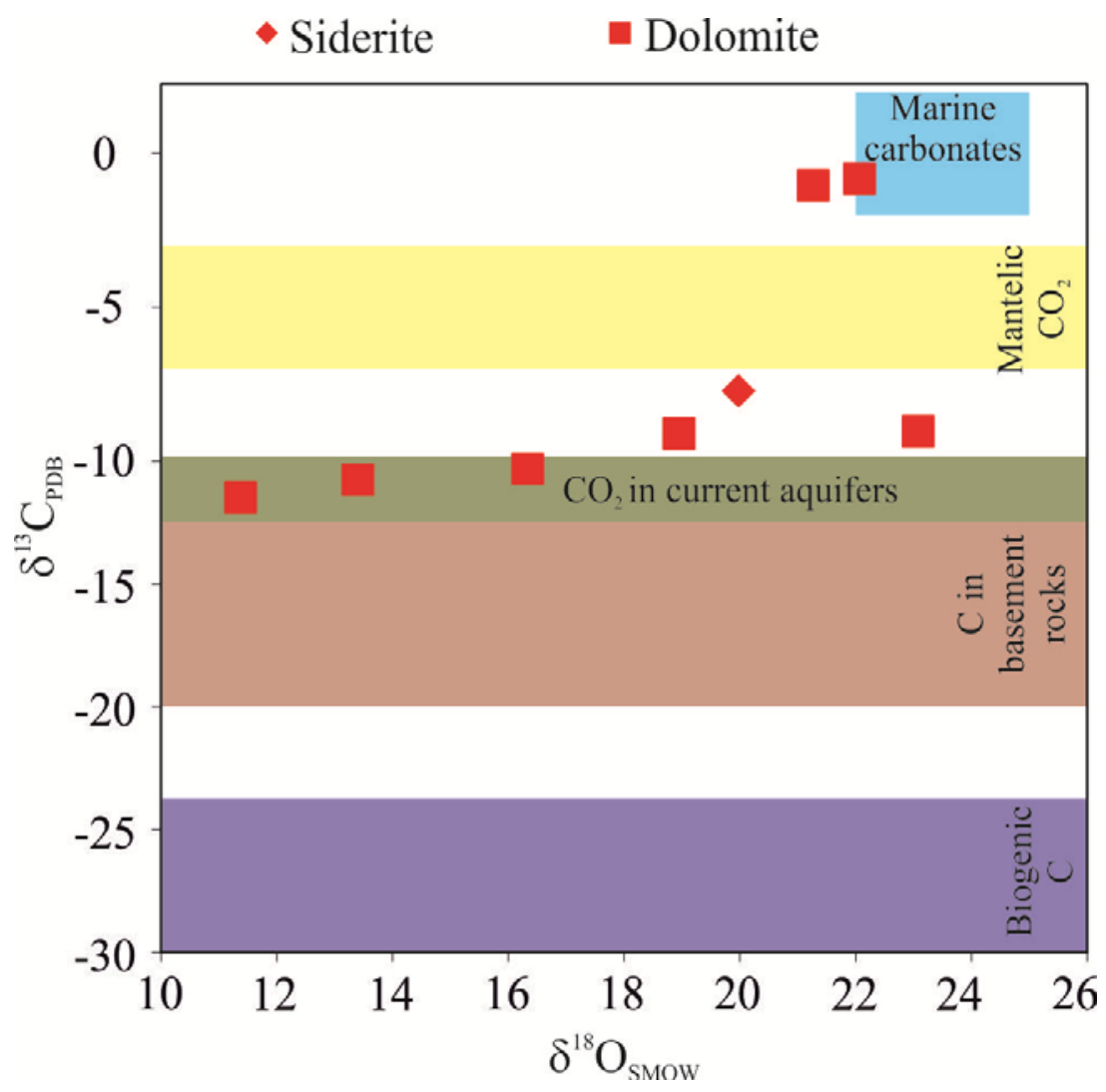

Hydrothermally altered rocks show variable ${ }^{87} \mathrm{Sr}^{86} \mathrm{Sr}_{\mathrm{i}}$, ranging from 0.7113 to 0.7155 , with no clear correspondence between alteration type and isotopic ratio (Fig. 10). Minerals from the veins (with the exception of one dolomite sample which also shows heavy out-ofrange carbon isotopic ratios) are characterized by a more homogeneous strontium signature than altered rocks. For barite this ${ }^{87} \mathrm{Sr} /{ }^{86} \mathrm{Sr}_{i}$ ratio shows the most radiogenic values of all the minerals: $0.7142-0.7143$ (Fig. 10). Carbonates show a slightly less radiogenic signature, with ${ }^{87} \mathrm{Sr} /{ }^{86} \mathrm{Sr}_{i}$ between 0.7128 and 0.7141 , with the exception of dolomite, with 0.7084 . Two jarosite samples show an ${ }^{87} \mathrm{Sr} /{ }^{86} \mathrm{Sr}_{\mathrm{i}}$ ratio of 0.7139 , similar to the values for dolomite and barite.

Geochronological analysis of illite concentrates from the argillic alteration zone indicates an age of $9.7 \pm 1.2 \mathrm{Ma}$, with $4.9 \% \mathrm{~K}$ and $1.9 \mathrm{Ar}$. rad. $\mathrm{nl} / \mathrm{g}$. This data fits within the time interval for volcanism in Mazarrón: $8.9 \pm 0.6 \mathrm{Ma}$ (Turner et al., 1999). 

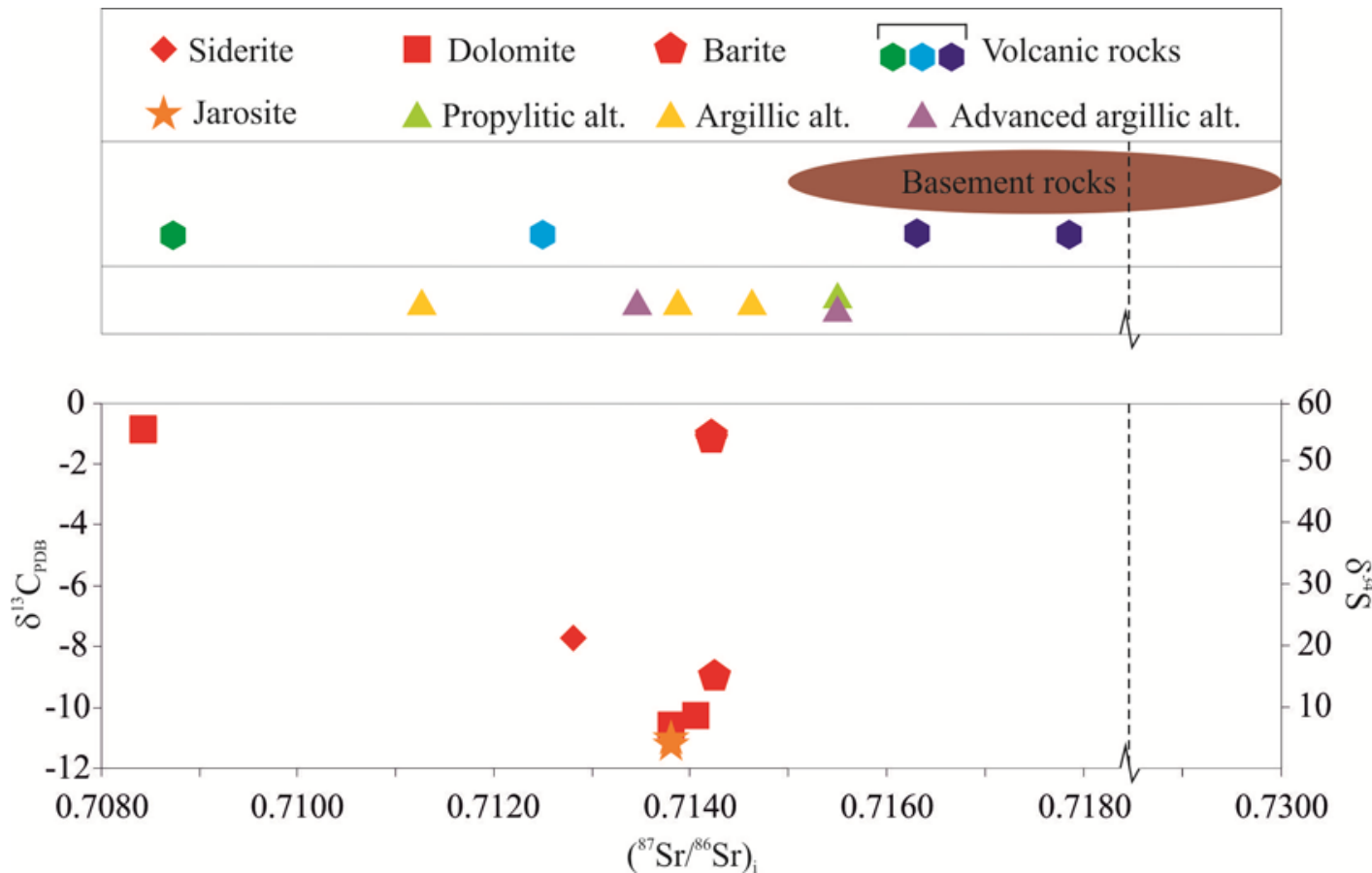

Figure 10: $\left({ }^{87} \mathrm{Sr}{ }^{86} \mathrm{Sr}\right)_{i}$ vs. $\delta^{13} C_{P C B}$ of carbonates and vs. $\delta^{34} \mathrm{~S}$ of sulfates. The $\left({ }^{87} \mathrm{Sr}{ }^{86} \mathrm{Sr}\right)_{i}$ ratios of unaltered volcanic rocks in the Mazarrón area are shown at the top of the diagram (Turner et al., 1999, green hexagon; Munksgaard, 1984, blue hexagon; Benito et al., 1999, dark blue hexagon). The shadowed zone shows the distribution of the Sr isotopic signature of metamorphic Betic basement rocks according to Arribas et al. (1995).

\section{Discussion}

\subsection{Sulfur derived from a magmatic source?}

The Mazarrón $\mathrm{Zn}-\mathrm{Pb}-\mathrm{Cu}-\mathrm{Ag}$ deposit shows typical characteristics of a volcanic-hosted epithermal deposit in terms of host rocks, style of mineralization, ore mineralogy, hydrothermal alteration and age of mineralization. Another typical feature of volcanichosted epithermal deposits is the magmatic origin of the sulfur, which usually has a narrow $\delta^{34} \mathrm{~S}$ range, generally around 0\% (Ohmoto and Goldhaber, 1997) or slightly positive values linked to the particular magma evolution: such as crustal material incorporation (i.e. evaporites; the case of some calc-alkaline magmas, e.g. Cavarretta and Lombardi, 1990; Ohmoto and Goldhaber, 1997; Ripley et al., 2007). However, the isotopic composition of sulfide sulfur from the Mazarrón ore deposit, with values of between $-2.9 \%$ o to $+28.4 \%$, is apparently incompatible with a single magmatic derived source. This range reduces significantly from +3.7 to $+12.3 \%$ o with a mode of circa $8 \%$ when only the $\mathrm{Zn}, \mathrm{Pb}$ and $\mathrm{Cu}$ sulphides (polymetallic association) are considered and the most enriched values are excluded. Available magmatic sulfur isotopic values for volcanic rocks in the Cabo de GataCartagena belt range between +0.6 and $+7.3 \%$ (calc-alkaline rhyolites and andesites around the Rodalquilar deposit, Arribas et al., 1995), which may suggest the incorporation in the magma of Triassic evaporites from the Betic basement due to assimilation or contamination in the magmatic source. This relatively heavy sulfur in Cabo de Gata- Cartagena vulcanites is compatible with the magmatic origin of other nearby epithermal deposits with positive $\delta^{34} \mathrm{~S}_{\text {sulfide }}$ and normal distribution (Rodalquilar and Carboneras: $\delta^{34} \mathrm{~S}_{\text {sulfide }}$ up to $8 \%$, Arribas et al., 1995 and Carrillo-Rosúa et al., 2003). This could also support the idea that some of the sulfur from the polymetallic sulfide association is magma-derived (i.e. relatively 
homogeneous $\delta^{34} \mathrm{~S}$, normal distribution with values only 2 to $5 \%$ heavier than possible magmatic distribution), while requiring in addition the intervention of other heavier nonmagmatic reduced sulfur sources.

In relation to the origin of the sulfates, enriched barite values of up to $+53.9 \%$ (Fig. 7 ) are incompatible with a magmatic source, as this would imply isotopic equilibrium below 100 -C (Ohmoto and Rye, 1979), an unrealistic temperature for sulfide-sulfate equilibrium, due above all to kinetic restrictions (Ohmoto and Lassaga, 1982). In the case of Fe-Al sulfates, the sulfur signature is similar to that of the sulfide range. This points to a possible origin by oxidation, but the unclear relationship with sulfides prevents us from differentiating between steam heated and modern supergenic conditions. The $\delta^{18} \mathrm{O}$ study in these minerals reveals the involvement of meteoric fluids but does not clarify the temperature, for which further in-depth study is required.

\subsection{The role of sulfate reduction in the Mazarrón deposit}

Since isotopic data rule out exclusive derivation from magmatic sulfur, another alternative source must be found. According to the very wide $\delta^{34} S_{\text {sulfide }}$ range the most likely sulfur origin could be the dissolved sulfate in the hydrothermal fluids, as occurs in most of the sediment-hosted strata-bound base-metal deposits or even in some volcanogenic-hosted massive sulfide deposits (Leach et al., 2005, Ohmoto and Lasaga, 1982, Machel et al., 2001). In the case of Mazarrón, evaporitic rocks from the basement could be dissolved by basinal fluids. Afterwards the sulfate moves and undergoes reduction during cooling of the magma, producing the $\mathrm{H}_{2} \mathrm{~S}$ responsible for Fe-sulfide association formation and part of the polymetallic sulfide mineral association (Fig. 11). A similar process of sulfate reduction was proposed for sediment-hosted epithermal deposits from Eastern Rhodopes (Moritz et al., 2014). However this mechanism is rarely proposed as an explanation for the origin of sulfur in classical volcanic-hosted epithermal deposits. In fact, to our knowledge, this is the first time it has been proposed.

Our data suggest that the $\delta^{34} \mathrm{~S}_{\text {sulfate-sulfide }}$ is between 18 and $25 \%$, taking the most depleted or the most enriched mineral-pairs (pyrite and barite). This range overlaps the fractionation observed in Thermochemical Sulfate Reduction -(TSR) $\leq 15-20 \%$ - and Bacterial Sulfate Reduction -(BSR) $\geq 15-20 \%$ - (Machel et al., 1995). The calculated temperature for the hydrothermal system $\left(190-260^{\circ} \mathrm{C}\right)$ rules out BSR, because the generation of reduced sulfur controlled by bacterial sulfate reduction (BSR) requires temperatures of less than $120^{\circ} \mathrm{C}$ (Stetter et al., 1990; Kashefi and Lovley, 2003). This temperature is also too high for TSR, which generally operates between 100-180ㄷ (Machel et al., 2001). Nevertheless, lower temperatures are expected in the vicinity of the veins, close to the host rocks where $\mathrm{H}_{2} \mathrm{~S}$ could probably generate. The evidence suggesting TSR rather than BSR are the very enriched values both for sulfide (up to $28.4 \%$ ) and sulfates (up to $53.9 \%$, one of the highest values detected in hydrothermal ore systems) associated with the enrichment trend (Fig. 8), which suggests the existence of a closed (or semi-closed) system. This would imply relatively high concentrations of $\mathrm{H}_{2} \mathrm{~S}$ in the system, which could inhibit bacterial activity (e.g. Reis et al., 1992).

According to this interpretation, sulfate leaching from Triassic evaporites from the basement (Espinosa-Godoy et al., 1974) could be the main primary source of sulfur. These sulfate-rich rocks were leached by basin waters and their sulfur was incorporated into the 
hydrothermal ore fluids (Fig. 11). This hypothesis fits with the following geological evidence: i) Triassic evaporites show $\delta^{34} \mathrm{~S}$ values of between +12 and $+17 \%$ (Utrilla et al., 1992; Gibert et al., 2007) close to our depleted barite values (15 to $19 \%$, Table 1), values that are incompatible with a Miocene sea water sulfate source (mean of $\delta^{34} \mathrm{~S} 12.4 \%$; Claypool et al., 1980 ); ii) Moderate to high salinity of the hydrothermal ore fluids (between +10 and +19 wt. \% $\mathrm{NaCl}$ eq. according to fluid inclusion data) compared with the lower salinity of standard epithermal deposits (typically between 0 and +12 wt. \% $\mathrm{NaCl} \mathrm{eq,} \mathrm{Wilkinson,} \mathrm{2001);}$ iii) The presence of a saline fluid, confined in the aquifer in the Mazarrón sedimentary basin displays $\delta^{34} S_{\text {sulfates }}$ around $+18 \%$ (Pérez del Villar et al., 1998). This fluid reservoir has sulfur with similar characteristics to the Triassic evaporitic rocks mentioned above.

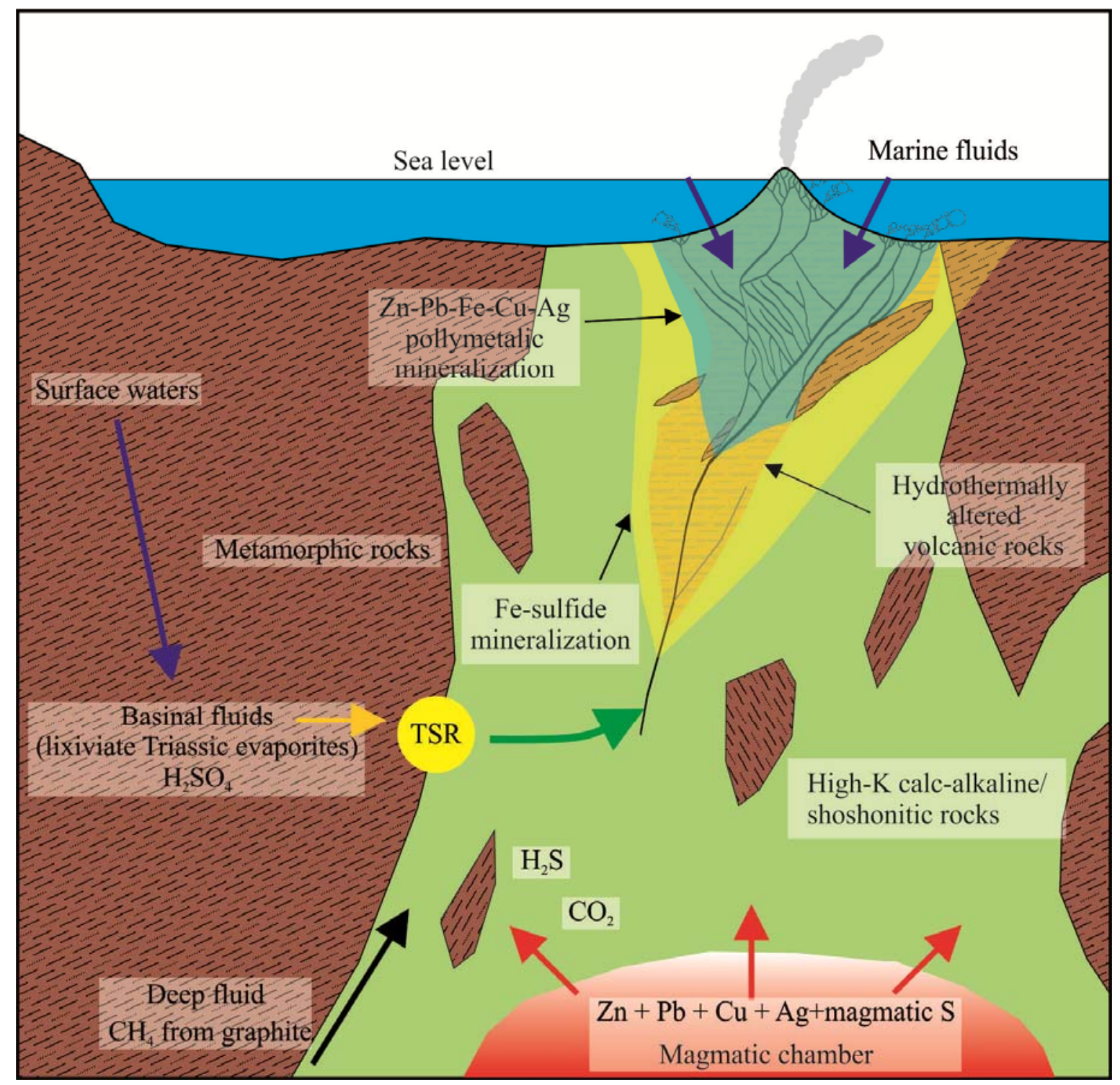

Figure 11: Schematic modelling of Mazarrón hydrothermal system. Upwelling hydrothermal hot fluid interacts with connate fluids, enriched in sulfates and in the presence of organic compounds $\left(\mathrm{CH}_{4}\right)$, and develops in thermochemical sulfate reduction (TSR). Some of the products $\left(\mathrm{H}_{2} \mathrm{~S} / \mathrm{HS}^{-}\right.$and $\left.\mathrm{CO}_{2} / \mathrm{HCO}_{3}^{-}\right)$are added to upwelling hydrothermal fluids (yellow arrows) and ascend, forming iron sulfides in shallower zones (disseminations and veins in yellow colour). This process is continuous, using the same connate water (semi-closed system). Zn-Pb-Cu-Ag mineralization corresponds to main magmatic pulse, with the predominance in this case of the magmatic $S$ source. 
The stable isotope geochemistry of carbonates also supports the idea of a sulfate reduction process, because it provides information about the sulfate reduction environment and further information about the fluid sources. Available results (Table 1) suggest that carbonate gangue is of partially organic origin, with carbon isotopic values that are more depleted than those for marine carbonate (Ohmoto and Rye, 1979) and lighter than typical magmatic or mantelic carbon $\left(\delta^{13} \mathrm{C}\right.$ between -7 to $-2 \%$; Javoy et al., 1986; Deines et al., 1991; Cartigny et al., 1998); in the case of two samples (M-893-B-1 and M-893-B-1-X) $\delta^{13} \mathrm{C}$ values are almost $0 \%$ (Table 1). This probably indicates a direct contribution of carbon from the seawater in line with the shallow nature of the hydrothermal system.

In the event of organic origin, a hypothetical source as a potent reduction agent could be hydrocarbons from the Neogene sedimentary basin. Nevertheless, published data indicate that organic-rich sediments in the area are associated with material from the late Messinian (<7 Ma, according to Sierro et al., 2001; Flores et al., 2005; Soria et al., 2008), and therefore appreciably younger than the volcanism (9.6-8.9 Ma; Turner et al., 1999, and Cesare et al., 2009) and the ore mineralization. A more likely alternative source could be the deep gas $\left(\mathrm{CH}_{4}\right)$ generated as a result of the metamorphism of the paleozoic basement, nowadays black schists which usually contain large amounts of graphite (Vera, 2004). This graphite shows an isotopic carbon signature in a wide range $\left(\delta^{13} \mathrm{C}-9.6\right.$ to $-20.2 \%$; Alt et al., 2012) similar to our data for carbonate. The decomposition of organic matter or even graphite to $\mathrm{CH}_{4}$ could be boosted by crustal anatexia and magmatic evolution related to the high-K calc-alkaline and shoshonitic magmas (Cesare et al., 2007). The generation of hydrocarbons associated with graphite devolatization is possible (Kolesnikov, 2010) within the range of temperatures and pressures reached in this region (Fig. 11). This could have caused the release of large amounts of light carbon which were incorporated into the hydrothermal fluids.

The existence of a deep source of carbon is also suggested in current aquifers near the Mazarrón deposit, in which the gas contains 70-90\% $\mathrm{CO}_{2}$ with minor $\mathrm{N}_{2}$ and $\mathrm{CH}_{4}$, and $\mathrm{He}$-like trace compounds (Pérez del Villar et al., 1998). Moreover $\mathrm{CO}_{2}$-rich reservoirs have been detected in the mine area at pressures of up to 42 atmospheres (Pilz, 1907; in Arana et al., 1993), characterized by $\delta^{13} \mathrm{C}$ in the range between -9.7 to $-12.6 \%$, which curiously is similar to that of carbonates with a biogenic carbon signature. These similar values suggest the same origin in both cases, i.e. the devolatization of metamorphic pile. This interpretation contrasts with that previously proposed by Crespo et al. (2013) in terms of source (mantelic) and age (developed in the Pliocene age).

\subsection{Origin of mineralization: genetic model}

The formation of the Mazarrón mineral deposit could be explained by the existence at depth of igneous intrusion, linked to volcanic activity in the area. Derived magmatic fluids from this intrusion interacted at depth with basinal fluids that leached basement rocks, including Triassic evaporites, producing the hydrothermal fluids that characterize this deposit. This interaction occurred in the presence of deep generated $\mathrm{CH}_{4}$ which led to sulfate reduction, with concomitant carbonate generation (Fig. 11). The progressive increasing $\delta^{34} S$ signature in iron sulfides indicates the existence of a continuous process of TSR, using a basinal fluid that worked as a closed system. In shallow areas these fluids develop veins and disseminations in volcanic rock and nearby basement, with the precipitation of iron sulfides. This precipitation occurs with the interaction of marine fluids (F1 fluid in Figure 6); the 
presence of fluid sources (basinal, magmatic, marine) is justified by calculated $\delta^{18} \mathrm{O}_{\text {fluid }}$ and ${ }^{87} \mathrm{Sr} /{ }^{86} \mathrm{Sr}_{i}$. In the first case, we obtained a $\delta^{18} \mathrm{O}_{\text {fluid }}$ range of +0.3 to +15.8 , for temperatures of between 190 and $260 \circ \mathrm{C}$ from fluid inclusion data, and isotope fractionation factors (Carothers et al., 1988, and Zheng, 1999; Table 1). In the case of Sr isotopes (Fig. 10), the heterogeneous ${ }^{87} \mathrm{Sr} /{ }^{86} \mathrm{Sr}_{\mathrm{i}}$, data (values between $0.7084-0.7155$ ) require the existence of fluids from basement (Triassic evaporites and limestones, Paleozoic schists; up to 0.7155) and marine sources $\left({ }^{87} \mathrm{Sr} /{ }^{86} \mathrm{Sr}_{i}=0.7091\right.$; Burke et al., 1982), and also proper volcanic rocks $\left({ }^{87} \mathrm{Sr} /{ }^{86} \mathrm{Sr}_{\mathrm{i}}=0.7087-0.7177\right)$. In the case of barite, the estimated $\delta^{18} \mathrm{O}$ for mineralizing fluid is 9.7-10.0\%o $\left(\delta^{18} \mathrm{O}_{\mathrm{SO} 4}=11.5\right)$ and $14.8-15.2 \%$ o $\left(\delta^{18} \mathrm{O}_{\mathrm{SO} 4}=16.6 \%\right.$. The first value is near the magmatic signature (8.7-11.1\%o; López Ruiz et al., 1991), but the second is clearly too high to be produced by a magmatic source. But both values are near or within the range for oxygen in Triassic evaporates (10.2-13.8\%; Utrilla et al., 1992).

The flow of dominant magmatic mineralizing fluids through the rocks generated the acid hydrothermal alteration of the surrounding volcanic edifice, with the development of propylitic, argillic, advanced argillic and silicification alteration zones, as in typical epithermal volcanic-hosted environments. The dating of this alteration has revealed that the mineralization process began at the same time or slightly later than high-K calc-alkalineshoshonitic volcanism; this relation is similar to that observed in other hydrothermal mineralizations in the Cabo de Gata-Cartagena Belt (Arribas et al., 1995; Carrillo-Rosúa, 2005).

The input of magmatic sulfur may also be responsible for the $\mathrm{Zn}, \mathrm{Pb}$ and $\mathrm{Cu}$ sulfide mineralizations. The isotopic features of this pulse suggest the involvement of an additional, more homogeneous sulfur source, such as $\mathrm{H}_{2} \mathrm{~S}$ from a magma-derived hydrothermal fluid. This fluid probably has a similar $\delta^{34} S$ signature to that observed in other magmatic epithermal systems in Cabo de Gata - Cartagena such as Rodalquilar or Carboneras: $\delta^{34} \mathrm{~S}$ around 5 - 8\% (Arribas et al., 1995; Carrillo-Rosúa et al., 2003). In shallow zones, it has mixed with the system in which sulfate reduction was taking place, producing $\mathrm{Zn}-\mathrm{Pb}-\mathrm{Cu}-\mathrm{Ag}$ mineralization.

\section{Conclusions}

The available geological and geochemical data indicate the existence of two unusual features in the Mazarrón epithermal deposit: firstly, the non-magmatic primary source of the sulfur, which probably leached from the Triassic evaporites and secondly, the fact that this origin requires the existence of TSR processes in closed or semi-closed conditions. The geological data and the new isotopic features described in this paper define the Mazarrón ore system as an unconventional example of volcanic-hosted epithermal deposits. The development of this hydrothermal system was coeval and linked to high-K calc-alkalineshoshonitic volcanism (9 Ma).

The most suitable carbon source for the development of TSR is organic matter (graphitized) present in metamorphic rocks from the basement and released during the metamorphic (+ anatexia) processes. It is worth noting that the above carbon source continues active today, providing a continuous carbon contribution to the aquifers in the form of aqueous $\mathrm{CO}_{2}$.

The mineralization of Mazarrón developed in two main pulses: firstly, in relation with the TSR process, forming the main Fe-sulfide mineral association and secondly, the main 
magmatic pulse generating the polymetallic mineral association. In both cases, ascending hydrothermal fluids interacted with surface waters, specifically marine fluids.

With all these characteristics Mazarrón deposit could be classified as an "intermediate" sulfidation system. This view contradicts the findings of Hedenquist et al. (2000), who considered Mazarrón an epithermal "low-sulfidation" deposit, and the "high sulfidation" type claimed more recently by Oyarzun et al. (2011). Our intermediate sulfidation classification is supported by the following arguments: i) High-K calc-alkaline and shoshonitic nature of the host rocks usually linked with intermediate sulfidation (Sillitoe and Hedenquist, 2003); ii) The presence of an ore association governed by base metal sulfides (i.e. sphalerite, galena and chalcopyrite), with abundant gangue dominated by carbonates with minor quartz, which are characteristic of low and intermediate sulfidation deposits (Sillitoe and Hedenquist, 2003; Camprubí et al., 2003); iii) The vein-style mineralization, more frequent in low and intermediate sulfidation deposits (Camprubí et al., 2003); and finally, iv) The typical acidic alteration, with the development of alteration halos, including advanced argillic (presence of alunite) and silicification zones, that do not usually appear in low sulfidation mineralizations (Hedenquist et al., 2000).

Acknowledgments This research has been supported by the RNM736 Excellence Project of the Junta de Andalucía and the CGL2006/02594/BTE Project of the Spanish Ministry of Innovation and Science and FEDER. We are indebted to technicians from the Scientific Instrumentation Center (CIC) in Granada (Spain) and the Scottish Universities Environmental Research Centre (SUERC) in East Kilbride (Scotland, United Kingdom) for their help with the analyses presented in this paper.

\section{References}

Alt, J.C., Garrido, C.J., Shanks III, W.C., Turchyn, A., Padrón-Navarta, J.A., Sánchez-Vizcaíno, V.L., Gómez Pugnaire, M.T., Marchesi, C., 2012. Recycling of water, carbon, and sulfur during subduction of serpentinites: A stable isotope study of Cerro del Almirez, Spain. Earth Planet. Sc. Lett. 327-328, 50-60.

Arana, R., Pérez Sirvent, C., Ortiz González, R., 1993. Explotaciones mineras e impacto ambiental en el sector de Mazarrón (Murcia). Problemática Geoambiental y Desarrollo: V Reunión Nacional de Geología Ambiental y Ordenación del Territorio, 811-834.

Arribas, A. Jr., Cunningham, C.G., Rytuba, J.J., Rye, R.O., Kelly, W.C., Podwysocki, M.H., McKee, E.H., Tosdal, R.M., 1995. Geology, geochronology, fluid inclusions, and isotope geochemistry of the Rodalquilar gold alunite deposit, Spain. Econ. Geol. 90, 795-822.

Arribas, A. Jr., Cunnningham, C.G., McKee, E.H., Rye, R.O., Rytuba, J.J., Tosdal, R.T., Wasserman, M.D., Aoki, M., 1995b. Compilation of sample preparation and analytical method and results of chemicals, isotopic, and fluid inclusion annalyses, Rodalquilar Ar alunite deposit Spain. U.S. Geological Survey Open-File Report 95-221, 33 p.

Arribas, A. Jr., Tosdal, R.M., 1994. Isotopic Composition of Pb in Ore Deposits of the Betic Cordillera, Spain: Origin and Relationship to Other European Deposits. Econ. Geol. 89, 1074-1093.

Benito, R., López Ruiz, J., Cebriá, J.M., Hertogen, J., Doblas, M., Oyarzun, R., Demaiffe, D., 1999. Sr and $\mathrm{O}$ isotope constraints on source and crustal contamination in the high-K calc-alkaline and shoshonitic neogene volcanic rocks of SE Spain. Lithos 46, 773-802. 
Blanco, M.J., Spakman, W., 1993. The P-wave velocity structure of the mantle below the Iberian Peninsula: Evidence for a subducted lithosphere below southern Spain. Tectonophysics 248, 274261.

Bodnar, R.J., Lecumberri-Sánchez, P., Moncada, D., Steele-Maclnnis, M., 2014. Fluid Inclusions in Hydrothermal Ore Deposits. In: Holand HD and Turekian KK (eds.) Treatise on Geochemistry, Second edition, Oxford: Elsevier, 13, pp. 119-142.

Burke, W.H., Denison, R.E., Hetherington, E.A., Koepnick, R.B., Nelson, H.F., Otto, J.B., 1982. Variation of seawater ${ }^{87} \mathrm{Sr} /{ }^{86} \mathrm{Sr}$ throughout Phanerozoic time. Geology 10, 516-519.

Camprubí, A., Albinson, T., 2006. Depósitos epitermales en México: actualización de su conocimiento y reclasificación empírica. Bol. Soc. Geol. Mex., LVIII-4, 27-81.

Camprubí, A., González-Partida, E., Levresse, G., Tritlla, J, Carrillo-Chávez, A., 2003. Depósitos epitermales de alta y baja sulfuración: una tabla comparativa: Bol. Soc. Geol. Mex., 56, 10-18.

Carothers, W.W., Adami, L.H., Rosenbauer, R.J., 1988. Experimental oxygen isotope fractionation between siderite-water and phosphoric acid liberated $\mathrm{CO}_{2}$-siderite. Geochim. Cosmochim. Ac. $52,2445-2450$.

Carrillo-Rosúa, J., 2005. El depósito epitermal de oro-cobre de Palai-Islica (Carboneras, Almeria). Mineralogía, geoquímica y metalogenia. Ph. D. Thesis, Univ. Granada, 421pp.

Carrillo-Rosúa, J., Morales Ruano, S., Boyce, A.J., Fallick, A.E., 2003. High and intermediate sulphidation environment in the same hydrothermal deposit: the example of $\mathrm{Au}$-Cu Palai-Islica deposit, Carboneras (Almería). In: Mineral exploration and sustainable development (Eliopoulos, D.G. et al., eds.). Millpress, Rotterdam, pp. 445-448.

Cartigny, P., Harris, J.W., Javoy, M., 1998. Eclogitic diamond formation at Jwaneng. No room for a recycled component. Science 280, 1421-1424.

Cavarretta, G., Lombardi, G. 1990. Origin of sulfur in the Quaternary perpotassic melts of Italy: Evidence from hauyne sulfur isotope data. Chem. Geol. 82, 15-20.

Cebriá, J.M., López Ruiz, J., Carmona, J., Doblas, M., 2008. Quantitative petrogenetic constraints on the Pliocene alkali basaltic volcanism of the SE Spain Volcanic Province. J. Volcanol. Geoth. Res. $185,172-180$.

Cesare, B., Maineri, C., Baron Toaldo, A., Pedron, D., Acosta-Vigil, A., 2007. Immiscibility between carbonic fluids and granitic melts during crustal anatexis: a fluid and melt inclusion study in the enclaves of the Neogene Volcanic Province of SE Spain. Chem. Geol. 237, 433-449.

Cesare, B., Rubatto, D., Gómez-Pugnaire, M.T., 2009. Do extrusion ages reflect magma generation processes at depth? An example from the Neogene Volcanic Province of SE Spain. Contrib. Mineral. Petr. 157, 267-279.

Claypool, G.E., Holser, W.T., Kaplan, I.R., Sakai, H., Zak, I., 1980. The age curves of sulfur and oxygen isotopes in marine sulfate and their mutual interpretation. Geochim. Cosmochim. Ac. 27, 43-52.

Coleman, M.L., Moore, M.P., 1978. Direct reduction of sulfate to sulfur dioxide for isotopic analysis. Anal. Chem. 50, 1594-1595.

Conticelli, S., Guarnieri, L., Farinelli, A., Avanzinelli, R., Mattei, M., Bianchini, G., Boari, E., Tommasini, S., Tiepolo, M., Prelevic, D., Venturelli, G., 2009. Trace elements and Sr-Nd-Pb isotopes of K-rich, shoshonitic, and calcalkaline magmatism of the Western Mediterranean Region: genesis of ultrapotassic to calc-alkaline magmatic associations in a post-collisional geodynamic setting. Lithos 107, 68-92.

Corbella, J.H., 1969. Etude géologique de la Sierra de las Moreras (Murcia, Espagne). Thèse 3ème cycle, Univ Paris 6, $158 \mathrm{pp}$. 
Craig, H., 1957. Isotopic standards and isotopic correction factors for mass spectrometric analysis of carbon dioxide. Geochim. Cosmochim. Ac. 12, 133-149.

Crespo, E., Lillo, J., Oyarzun, R., Cubas, P., Leal, M., 2013. The Mazarrón basin, SE Spain: A study of mineralization processes, evolving magmatic series, and geothermal activity. Int. Geol. Rev. 55(16), 1978-1990.

Deines, P., Harris, J.W., Gurney, J.J., 1991. The carbon isotopic composition and nitrogen content of lithospheric and asthenospheric diamonds from the Jagersfontein and Koffiefotein kimberlite, South Africa. Geochim. Cosmochim. Ac. 55, 2615-2625.

Dietrich, G., Kalle, K., 1963. General Oceanography: an Introduction. Wiley, 588 pp.

Duggen, S., Hoernle, K., Bogaard, P.V.D., Garbe-Schönberg, D., 2005. Post-collisional transition from subduction- to intraplate-type magmatism in the westernmost Mediterranean: Evidence for continental-edge delamination of subcontinental lithosphere. J. Petrol. 46, 1155-1201.

Duggen, S., Hoernle, K., Klügel, A., Geldmacher, J., Thirlwall, M., Hauff, F., Lowry, D., Oates, N., 2008. Geochemical zonation of the Miocene Alborán Basin volcanism (westernmost Mediterranean): geodynamic implications. Contrib. Mineral. Petrol. 156, 577-593.

Espinosa Godoy, J., Martín Vivaldi, J.M., Herrera López, J.L., Pérez Rojas, A., 1974. Mapa Geológico de España, e: 1:50.000, hoja 976 (Mazarrón), I.G.M.E.

Flores, J.A., Sierro, F.J., Filippelli, G.M., Bárcena, M.A., Pérez-Folgado, M., Vázquez, A., Utrilla, R., 2005. Surface water dynamics and phytoplankton communities during deposition of cyclic late Messinian sapropel sequences in the western Mediterranean. Mar. Micropaleontol. 56, 50-79.

Gibert, L., Ortí, F., Rosell, L., 2007. Plio-Pleistocene lacustrine evaporites of the Baza Basin (Betic Chain, SE Spain). Sed. Geol. 200, 89-116.

Guillén-Riquelme, M.C., 1997. Mazarrón,1900. Mazarrón City Hall eds. 267 pp.

Hall, A.J., Boyce, A.J., Fallick, A.E., Hamilton, P.J., 1991. Isotopic evidence of the depositional environment of Late Proterozoic stratiform barite mineralisation, Aberfeldy, Scotland. Chem. Geol. (Isotope Geosciences. Section) 87, 99-114.

Hedenquist, J.W., Arribas, A. Jr., González Urien, E., 2000. Exploration for epithermal gold deposits in Hagemann S. G. and Brown P. E. (Eds.) Gold in 2000, Reviews in Econ. Geol., v. 13, Chapter 7, 245-277.

Hedenquist, J.W., Lowenstern, J.B., 1994. The role of magmas in the formation of hydrothermal ore deposits. Nature 370, 519-527.

Javoy, M., Pineau, F., Delorme, H., 1986. Carbon and nitrogen isotopes in the mantle. Chem. Geol. $57,41-62$.

Kashefi, K., Lovley, D.R., 2003. Extending the upper temperature limit for life. Science 301, 934.

Kelley, S.P., Fallick, A.E., 1990. High precision spatially resolved analysis of $\delta^{34} S$ in sulfides using a laser extraction technique. Geochim. Cosmochim. Ac. 54, 883-888.

Kolesnikov, A., 2010. Experimental investigation of hydrocarbons formation and transformation under Earth's upper mantle conditions. Ph. D. Thesis, KTH Energy and Environmental Technology, 69pp.

Leach, D.L., Sangster, D.F., Kelley, K.D., Large, R.R., Gatven, G., Allen, C.R., Gutzmer, J., Walters, S., 2005. Sediment-hosted lead-zinc deposits: A global perspective. Econ. Geol. 100TH ANNIVERSARY VOLUME, 561-607.

López-Ruiz, J., Rodriguez-Badiola, E., 1980. La región volcánica del sureste de España. Estud. Geol. 36, 5-63. 
López-Ruiz, J., Wasserman, M.D., 1991. Relación entre la hidratación/desvitrificación y el 018 en las rocas volcánicas neógenas del SE de España. Estud. Geol. 47, 3-11.

Machel, H.G., 2001. Bacterial and thermochemical sulfate reduction in diagenetic settings - old and new insights. Sediment. Geol. 140, 143-175.

Machel, H.G., Krouse, H.R., Sassen, R., 1995. Products and distinguishing criteria of bacterial and thermochemical sulfate reduction. Appl. Geochem. 10, 373-389.

Manteca Martínez, J.I., Pérez de Perceval Verde, M.A., López-Morel, M.A., 2005. La industria minera en Murcia durante la época contemporánea. In: A.A.V.V. Bocamina, Editor, Patrimonio Geológico y Minero de la Región de Murcia, Museo de la Ciencia y el Agua, Murcia, pp. 123-134.

Martín Ramos, J.D., 2004. XPowder, a software package for powder X-ray diffraction analysis. Legal Deposit GR 1001/04.

Mathsuhisa, Y., Goldsmith, H.J.R., Clayton, R.N., 1979. Oxygen isotopic fractionation in the system quartz-albite-anorthite-water. Geochim. Cosmochim. Ac 43, 1131-1140.

Morales Ruano, S., Carrillo Rosúa, F.J., Fenoll Hach-Alí, P., De la Fuente Chacón, F., Contreras López, E., 2000. Epithermal Cu-Au mineralization in the Palai-Islica deposit, Almería, Southeastern Spain: fluid-inclusion evidence for mixing of fluids as a guide to gold mineralization. Can. Mineral. 38, 553-565.

Morales Ruano, S., Fenoll Hach-Alí P., 1990. Mineralizaciones asociadas a rocas volcánicas del distrito de Mazarrón (Murcia). Geoquímica y metalogenia. Bol. Soc. Esp. Min. 13-1, 58.

Moritz, R., Noverraz, C., Márton, I., Marchev, P., Spikings, R., Fontignie, D., Spangenberg, J.E., Vennemann, T., Kolev, K., Hasson, S., 2014. Sedimentary-rock-hosted epithermal systems of the Tertiary Eastern Rhodopes, Bulgaria: new constraints from the Stremtsi gold prospect. In: GoldTransporting Hydrothermal Fluids in the Earth's Crust (Garofalo PS and Ridley JR eds.). Geological Society, London, Special Publications 402, pp. 207-230.

Munksgaard, N.C., 1984. High $\delta^{18} \mathrm{O}$ and possible pre-eruptional $\mathrm{Rb} / \mathrm{Sr}$ isochrons in cordierite-bearing Neogene volcanics from SE Spain. Contrib. Mineral. Petrol. 87, 351-358.

Ohmoto, H., Goldhaber, M.B., 1997. Sulfur and Carbon Isotopes. In: Geochemistry of hydrothermal ore deposit. (Barnes, H.L. ed.). John Wiley \& Sons, New York, 3th ed., pp. 517-611.

Ohmoto, H., Lasaga, A.C., 1982. Kinetics of reaction between aqueous sulfates and sulfides in hydrothermal systems. Geochim. Cosmochim. Ac. 46, 1727-1746.

Ohmoto, H., Rye, R.O., 1979. Isotopes of sulfur and carbon. In: Geochemistry of hydrothermal ore deposit. (Barnes, H. L. ed.). John Wiley \& Sons, New York, $2^{\text {nd }}$ ed., pp. 509-567.

Oyarzun, R., Lillo, J., López-García, J.A., Esbrí, J.M., Cubas, P., Llanos, W., Higueras, P., 2011. The Mazarrón $\mathrm{Pb}-(\mathrm{Ag})-\mathrm{Zn}$ mining district (SE Spain) as a source of heavy metal contamination in a semiarid realm: Geochemical data from mine wastes, soils, and stream sediments. J. Geochem. Explor. 109 (1-3), 113-124.

Peccerillo, A., Martinotti, G., 2006. The Western Mediterranean lamproitic magmatism: origin and geodynamic significance. Terra Nova 18, 109-117.

Pérez del Villar, L., Pelayo, M., Prado, A.J., Recreo, F., Vilanova, E., Grandia, F., Duro, L., Doménech, C., Martel, M., Delgado, A., Auqué, L.F., Gimeno, M.J., Acero, P., 1998. Almacenamiento Geológico de $\mathrm{CO}_{2}$ : Análogos naturales del almacenamiento y escape. Fundamentos, ejemplos y aplicaciones para la predicción de riesgos y la evaluación del comportamiento a largo plazo. 9 Congreso Nacional del Medio Ambiente, Cumbre del Desarrollo Sostenible, 35 pp.

Pilz, R. 1907. Die Bleiglanzlagerstätten von Mazarrón in Spanien. Ph. D. Thesis, Freiberg University. 
Reis, M.A.M., Almeida, J.S., Lemos, P.C., Carrondo, M.J.T., 1992. Effect of hydrogen sulfide on growth of sulfate-reducing bacteria. Biotechnol. Bioeng. 40, 593-600.

Ripley, E.M., Li, C., Clague, D.A., 2007. The role of crustal sulfur in mafic magmas: perspectives from studies of sulfur isotope compositions. American Geophysical Union, Fall Meeting 2007, abstract \#V41C-07.

Robinson, B.W., Kusakable, M., 1975. Quantitative preparation of $\mathrm{SO}_{2}$ for ${ }^{34} \mathrm{~S} /{ }^{32} \mathrm{~S}$ analyses from sulfides by combustion with cuprous oxide. Anal. Chem. 47, 1179-1181.

Rodríguez, P., Hidalgo, R., 1997. Valoración de los recursos minerales en el núcleo minero de Mazarrón. A. Navarro Flores and L. García-Rosell Martínez, Editors, Recursos Naturales y Medio Ambiente en el Sureste Peninsular, Instituto de Estudios Almerienses, Almería pp. 253-267.

Roedder, E., 1984. Fluid inclusions. Mineral Soc Am, Washington, DC Rev. Mineral. 12, 644 pp.

Shepherd, T., Rankin, A.H., Alderton, D.H.M., 1985. A practical guide to fluid inclusion studies. Blackie, Glasgow and London, $239 \mathrm{pp}$.

Sierro, F.J., Hilgen, F.J., Krijgsman, W., Flores, J.A., 2001. The Abad composite (SE Spain): a Mediterranean and global reference section for the Messinian. Palaeogeogr. Palaeoclimatol. Palaeoecol. 168, 141- 169.

Sillitoe, R.H. and Hedenquist, J.W., 2003. Linkages between Volcanotectonic Settings, Ore-Fluid Compositions, and Epithermal Precious Metal Deposits. Soc. Econ. Geol., Special Publication Series 10, 314-343.

Soria, J.M., Caracuel, J.E., Corbí, H., Dinarès-Turell, J., Lancis, C., Tent-Manclús, J.E., Viseras, C., Yébenes, A., 2008. The Messinian-early Pliocene stratigraphic record in the southern Bajo Segura Basin (Betic Cordillera, Spain): Implications for the Mediterranean salinity crisis. Sediment. Geol. 203, 267-288.

Stetter, K.O., Fiala, G., Huber, G., Huber, R., Segerer, A., 1990. Hyperthermophilic microorganisms. FEMS Microbiology Reviews 75, 117-124.

Turner, S.P., Platt, J.P., George, R.M.M., Kelley, S.P., Pearson, D.G., Nowell, G.M., 1999. Magmatism associated with orogenic collapse of the Betic-Alboran domain, SE Spain. J. Petrol. 40, 10111036.

Utrilla, R., Pierre, C., Orti, F., Pueyo, J.J., 1992. Oxygen and sulfur isotope compositions as indicators of the origin of Mesozoic and Cenozoic evaporites from Spain. Chem. Geol. (Isot. Geosci. Sect.) $102,229-244$.

Vera, J.A. (Ed.), 2004. Geología de España. Sociedad Geológica de España-Instituto Geológico y Minero de España (SGE-IGME), Madrid, 884p.

Vogel, J.C., 1993. Variability of Carbon Isotope Fractionation during Photosynthesis. Stable Isotopes and Plant Carbon-water Relations, 29-46.

Wagner, T., Boyce, A.J., Fallick, A.E., 2002. Laser combustion analysis of $\delta^{34} S$ of sulfosalt minerals: determination of the fractionation systematics and some crystal-chemical considerations. Geochim. Cosmochim. Ac. 66, 2855-2863.

Wilkinson, J.J., 2001. Fluid Inclusions in hydrothermal ore deposits. Lithos 55, 229-272.

X'Pert HighScore Plus, Version 2.2d, PANalytical BV, 2004.

Zheng, Y.F., 1999. Oxygen isotope fractionation in carbonate and sulfate minerals. Geochem. J. 33, 109-126. 